\title{
Plasminogen Activators in Neurovascular and Neurodegenerative Disorders
}

\author{
Manuel Yepes ${ }^{1,2,3, * \mathbb{D}}$, Yena Woo ${ }^{2} \mathbb{D}$ and Cynthia Martin-Jimenez ${ }^{2}$ \\ 1 Department of Neurology, Emory University, Atlanta, GA 30329, USA \\ 2 Neuropharmacology and Neurological Diseases Section, Yerkes National Primate Research Center, \\ Atlanta, GA 30329, USA; yena.woo@emory.edu (Y.W.); \\ cynthia.alexandra.martin-jimemez@emory.edu (C.M.-J.) \\ 3 Department of Neurology, Veterans Affairs Medical Center, Decatur, GA 30329, USA \\ * Correspondence: myepes@emory.edu
}

Citation: Yepes, M.; Woo, Y.; Martin-Jimenez, C. Plasminogen Activators in Neurovascular and Neurodegenerative Disorders. Int. J. Mol. Sci. 2021, 22, 4380. https:// doi.org/10.3390/ijms22094380

Academic Editor: Hau C. Kwaan

Received: 18 March 2021

Accepted: 20 April 2021

Published: 22 April 2021

Publisher's Note: MDPI stays neutral with regard to jurisdictional claims in published maps and institutional affiliations.

Copyright: (c) 2021 by the authors. Licensee MDPI, Basel, Switzerland. This article is an open access article distributed under the terms and conditions of the Creative Commons Attribution (CC BY) license (https:/ / creativecommons.org/licenses/by/ $4.0 /)$.

\begin{abstract}
The neurovascular unit (NVU) is a dynamic structure assembled by endothelial cells surrounded by a basement membrane, pericytes, astrocytes, microglia and neurons. A carefully coordinated interplay between these cellular and non-cellular components is required to maintain normal neuronal function, and in line with these observations, a growing body of evidence has linked NVU dysfunction to neurodegeneration. Plasminogen activators catalyze the conversion of the zymogen plasminogen into the two-chain protease plasmin, which in turn triggers a plethora of physiological events including wound healing, angiogenesis, cell migration and inflammation. The last four decades of research have revealed that the two mammalian plasminogen activators, tissue-type plasminogen activator (tPA) and urokinase-type plasminogen activator (uPA), are pivotal regulators of NVU function during physiological and pathological conditions. Here, we will review the most relevant data on their expression and function in the NVU and their role in neurovascular and neurodegenerative disorders.
\end{abstract}

Keywords: tissue-type plasminogen activator (tPA); urokinase-type plasminogen activator (uPA); neurodegeneration

\section{Introduction}

The plasminogen activation system is assembled by a cascade of proteases and their inhibitors that catalyze the conversion of the zymogen plasminogen into the two-chain protease plasmin (Figure 1). Plasminogen is a $90 \mathrm{kDa}$ single-chain multidomain glycoprotein produced mainly in the liver [1] and assembled by 791 amino acids distributed in seven different structural domains: an N-terminal pre-activation peptide, 5 kringle domains and a C-terminal trypsin-like serine protease domain that harbors the catalytic triad His603, Asp646 and Ser741 [2]. Plasminogen binds to a plethora of highly heterogenous receptors on the cell surface, and this interaction not only triggers the generation of plasmin, but also activates cell signaling pathways that orchestrate a wide variety of functions including wound healing, angiogenesis, cell migration and inflammation [3]. Cleavage of plasminogen at the Arg561-Val562 bond by one of the two main plasminogen activators [tissue-type plasminogen activator (tPA) and urokinase-type plasminogen activator (uPA)] generates a two-chain plasmin molecule assembled by an N-terminal heavy-chain and a disulfidelinked C-terminal light chain containing the proteolytically active site. Importantly, the conversion of plasminogen into plasmin is enhanced when plasminogen is bound to fibrin or to the cell surface [4]. The generation of plasmin is tightly controlled at different steps of the plasminogen activating system. Accordingly, while plasminogen activator inhibitor-1 (PAI-1) and plasminogen activator inhibitor-2 (PAI-2) antagonize the proteolytic effect of tPA and uPA [5], $\alpha_{2}$-antiplasmin inhibits plasmin. In the intravascular space, plasmin acts not only as an effector of the fibrinolytic system by degrading fibrin, but also as an 
immune regulator [6]. Likewise, on the cell surface plasmin triggers the degradation of multiple components of the extracellular matrix (ECM) and basement membrane, including collagen, vitronectin, laminin, fibronectin and proteoglycans.

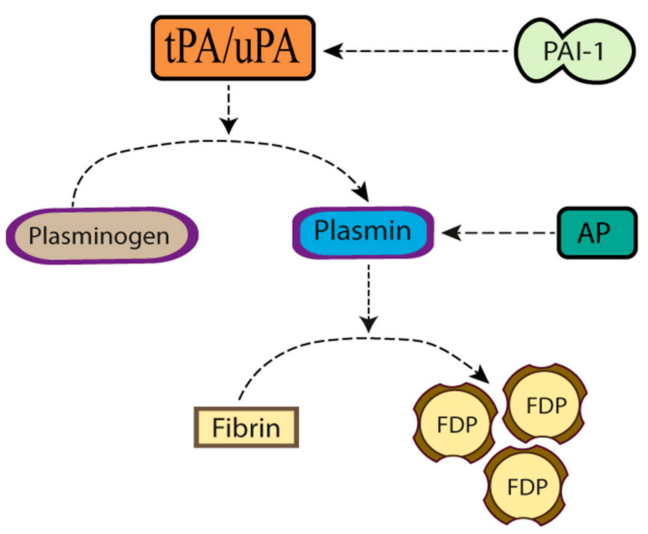

Figure 1. The plasminogen activating system. tPA: tissue-type plasminogen activator. uPA: urokinasetype plasminogen activator. AP: antiplasmin. PAI-1: plasminogen activator inhibitor-1. FDP: fibrin degradation products.

\section{The Neurovascular Unit}

The concept of the neurovascular unit (NVU) describes a dynamic interaction in the central nervous system between endothelial cells ensheathed by a basement membrane, and surrounding pericytes, astrocytes, microglia and neurons (Figure 2). The nature of the interplay between these cellular and non-cellular components has led to the proposal that the NVU is a single functioning unit responsible for the maintenance of cerebral hemostasis [7].

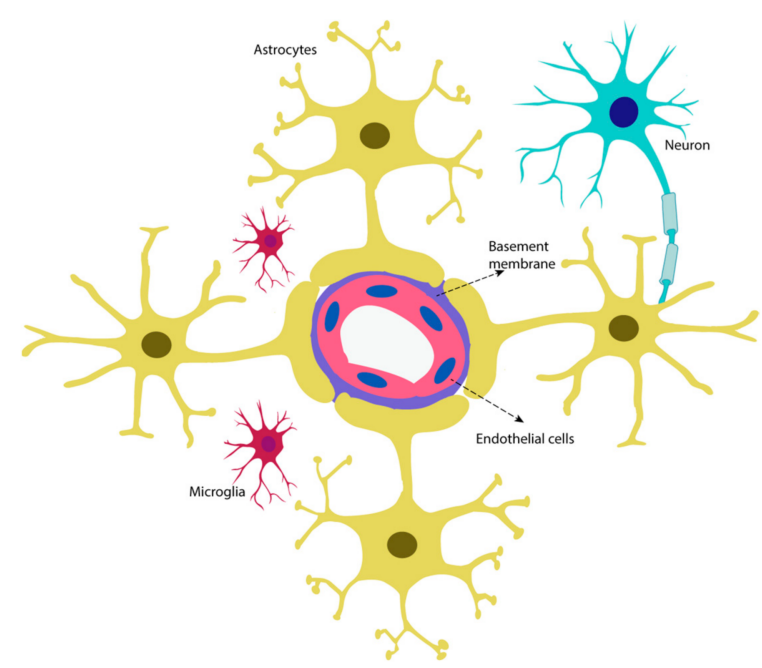

Figure 2. The neurovascular unit. Schematic representation of the cellular and non-cellular components of the neurovascular unit.

\section{Plasminogen Activators in the Neurovascular Unit under Physiological Conditions}

\subsection{Tissue-Type Plasminogen Activator}

Tissue-type plasminogen activator (tPA) is a 70-kDa serine proteinase secreted as a single-chain form (that upon its cleavage by plasmin at Arg275-Ile276 generates an active two-chain form held together by disulfide bonds). The tPA molecule is assembled by four domains: an amino-terminal region (fibronectin-like or finger domain), an EGF-like domain, two kringles and one serine protease region that harbors the active site residues His322, 
Asp371 and Ser478 [8]. In the neurovascular unit (NVU), tPA is found in endothelial cells, perivascular astrocytes, microglia, pericytes and neurons $[9,10]$.

\subsection{Tissue-Type Plasminogen Activator in the Neurovascular Unit \\ 3.2.1. Cerebral Endothelial Cells}

In endothelial cells tPA is stored in Weibel-Palade bodies, the specialized endothelial storage granules for von Willebrand factor [11]. The expression of tPA is increased at the transcriptional level in endothelial cells by a variety of stimuli, including vascular endothelial growth factor (VEGF), fluid shear stress, thrombin and histamine [12-14]. In turn, its release from a preformed pool is triggered by physical activity, $\beta$-adrenergic drugs, cholinergic agents, disseminated intravascular coagulation and hypoxia $[15,16]$. Studies with a primary monoclonal antibody that detected free and PAI-1-complexed human tPA revealed that in the non-human primate brain, tPA is found in a reduced number of endothelial cells of the microvasculature, most of them pre-capillary arterioles and postcapillary veins [17]. However, despite the relevance of these data, it is important to consider that since this report was published almost 3 decades ago no further effort has been made to characterize the expression of tPA with newer antibodies in endothelial cells of the brain. Finally, although tPA has been detected in in vitro lines of human microvascular endothelial cells [18], no in vivo studies have been published describing the expression of tPA in blood vessels of the human brain.

\subsubsection{Pericytes}

Very few studies have assessed the expression and function of tPA in pericytes. However, the few that have been published to this date indicate that zinc prompts the release of tPA from these cells [19], and that pericytes negatively regulate fibrinolysis-triggered endothelial cell-derived tPA [20].

\subsubsection{Astrocytes}

tPA is abundantly found in astrocytes, and several stimuli including hypoxia [21] and mechanical injury [22] trigger its release, both in vivo and in vitro. In line with these observations, tPA activates the NF- $\mathrm{kB}$ pathway in astrocytes [23], and its release into the basement membrane increases the permeability of the NVU [21]. The mechanism whereby tPA activates the NF- $\mathrm{kB}$ pathway is not completely understood. However, work with cerebral cortical astrocytes and rat kidney interstitial fibroblasts (NRK-49F) [24] revealed that the interaction between IPA and LRP1 triggers the phosphorylation of IKK $\alpha$, which then allows p65/p50 to translocate to the nucleus [25]. Further work with kidney cells has shown that another mechanism whereby tPA activates the NF- $\mathrm{kB}$ is by triggering annexin 2-mediated aggregation of the integrin $\mathrm{CD} 11 \mathrm{~B}$, which in turn prompts the phosphorylation of IK $\beta$ with the resultant nuclear translocation of p65/p50 [26] (Figure 3). In addition to its proinflammatory effect, an increase in the expression and activity of astrocytic tPA induced by multipotent mesenchymal stromal cells has been associated with neurite growth [27]. Furthermore, it has been proposed that astrocytes recycle tPA released in the synaptic cleft in response to glutamatergic signals [28], and that tPA released from astrocytes modulates the microglial response to endotoxins [29]. Together, these data indicate that the release of astrocytic tPA plays a pivotal role in the NVU as a regulator of the permeability of the astrocyte-basement membrane-endothelial cell interface, synaptic transmission, neuroinflammation and microglial function. 


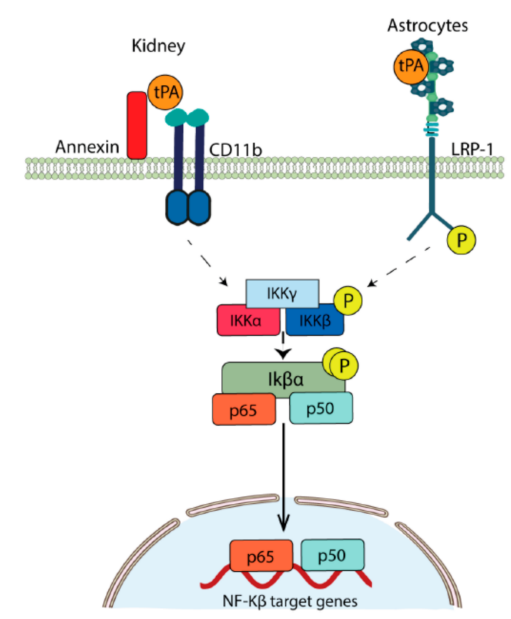

Figure 3. Mechanisms of tPA-induced NF- $\mathrm{kB}$ activation. Representative diagram of the proposed mechanisms whereby tPA activates the NF- $\mathrm{BB}$ pathway in the kidney and cerebral cortical astrocytes. In both cases, IKB $\alpha$ phosphorylation is followed by the nuclear translocation of p65/p50.

\subsection{4. tPA in Microglia}

Inasmuch as a functional link between tPA and microglial activation has been experimentally demonstrated, it is not clear if microglia release tPA. However, it has been proposed that injured neurons release tPA, and that this tPA triggers the release of microglial tPA, which in turn causes neurodegeneration [30]. Independently of these considerations, experimental evidence indicates that IPA mediates endotoxin- and kainic acid-induced microglial activation via an annexin II-mediated mechanism [31] that does not require plasmin generation [32] and triggers neuronal apoptosis [33].

\subsubsection{Neuronal tPA}

Neurons are a major reservoir of tPA in the central nervous system (CNS), and the release of neuronal tPA in the developing and mature brain plays a central role in the regulation of synaptic function and the response of the CNS to a variety of injuries. Indeed, the release of tPA by neuronal growth cones in the developing brain [34] induces neuronal migration [35] and neurite outgrowth and remodeling [36]. Noticeably, a similar sequence of events in the mature brain promotes neuronal recovery following an ischemic injury $[37,38]$. In contrast with the developing CNS, in situ zymography studies have revealed that only well-defined areas of the mature brain exhibit tPA-catalyzed proteolytic activity, namely the hippocampus, hypothalamus, thalamus, amygdala, cerebellum and meningeal blood vessels [39]. Furthermore, the interaction of tPA with $N$-methyl-D-aspartate (NMDA) receptors in these structures [40] regulates glutamatergic neurotransmission [41] and promotes the development of synaptic plasticity, as demonstrated in in vitro and in vivo models of long-term potentiation [42], learning [43,44], stress-induced anxiety [45] and visual cortex plasticity [37].

\subsection{Urokinase-Type Plasminogen Activator}

Urokinase-type plasminogen activator (uPA) is a $53 \mathrm{kDa}$ serine proteinase secreted as a single-chain uPA (scuPA) with 411 amino acids assembled into three domains: an $\mathrm{N}$-terminal domain homologous to the epidermal growth factor (responsible for its binding to uPAR), a kringle domain that interacts with plasminogen activator inhibitor-1 (PAI-1) and a C-terminal catalytic domain that harbors the active site with the His204, Asp255 and Ser356 amino acids triad [46]. The binding of scuPA to its receptor (uPAR) triggers its cleavage at K158-I159, thus prompting its conversion into an active two-chain form (tcuPA), with an A chain with the epidermal growth factor and kringle domains, and a B chain with the proteolytic domain [47]. In turn, tcuPA catalyzes the conversion of plasminogen into plasmin on the cell surface [48]. 
The receptor for uPA (UPAR) has 270 amino acids assembled into three cysteinerich Cd59-like sequence domains (D1, D2 and D3) connected by short linker regions and bound to the surface of the plasma membrane by a glycosyl phosphatidylinositol (GPI) tail. Regulation of UPAR is accomplished by either an inactivating uPA-induced cleavage of the receptor between D1 and D2, or by endocytosis of a PAI-1-uPA-uPAR low-density lipoprotein receptor-related protein-1 (LRP1) complex assembled on the cell surface, which then recycles free uPAR back to the membrane to bind to more uPA [49].

\subsection{Urokinase-Type Plasminogen Activator in the Neurovascular Unit (NVU)}

\subsubsection{Cerebral Endothelial Cells}

A substantial body of experimental evidence indicates that uPA and UPAR are found in endothelial cells [50], and that the release of this uPA and the increase in the expression of uPAR in endothelial cells triggered by a variety of stimuli $[51,52]$ induces cell migration, angiogenesis [53] and capillary branching. However, it is important to take into account that most of these studies have been performed with cell lines, and that very few studies have assessed the in vivo expression of uPA in cerebral endothelial cells. With that in mind, it has been reported that Cryptococcus neoformans increases the expression of uPA in cerebral endothelial cells [54], and that microvascular endothelial cells upregulate uPA following an ischemic injury to the spinal cord in vivo [55].

\subsubsection{Astrocytes and Microglia}

The abundance of uPA and uPAR is increased in glial cell tumors, particularly glioblastoma multiforme, where they have been reported to play a role in tumor growth [56]. In contrast, the role of astrocytic UPA and uPAR under physiological conditions is less well understood. However, recent studies indicate that the release of uPA under physiological conditions triggers astrocytic activation [57] and induces the formation of peripheral astrocytic processes [58]. The expression and role of microglial uPA and uPAR under non-pathological conditions is largely unknown, although in vitro studies have shown that endotoxins, kainic acid and neurogeneration increase their abundance in microglia [59].

\subsubsection{Neurons}

Despite the fact that uPA and uPAR are abundantly found in developing neurons [60-62], their expression changes dramatically over a few days. Hence, while day in vitro (DIV) 3 neurons harbor uPAR in their cell body and neurites, at DIV 7 the expression of this receptor shifts to the axon shaft and growth cones, and at DIV 16 is restricted to the distal segment of some axons and very few growth cones [60]. Significantly, uPA/uPAR binding during the early stages of development induces neuritogenesis and neuronal migration via a plethora of mechanisms that do not always require plasmin generation [63,64]. More specifically, by promoting activation of integrins and the focal kinase adhesion (FAK) pathway, uPAR regulates the reorganization of the cytoskeleton [63], thus triggering axonal growth, neuronal migration [65] and dendritic branching [66]. In line with these observations, uPAR seems to be pivotal for the formation of neuronal circuits that underlie the development of language and cognition, and dysregulation of the uPA/uPAR system has been linked to epilepsy and cognitive and developmental disorders [67].

In contrast, the expression and role of uPA/uPAR in the mature brain have been less studied. However, recent studies with human, murine and non-human primate brains indicate that UPA is abundantly found in synapses of the second and fifth cortical layers of the cerebral cortex, and that uPA/uPAR binding modulates excitatory neurotransmission by regulating the synaptic expression of neuronal cadherin (NCAD) [68]. Additionally, these studies showed that UPA induces the expression of NCAD in the synapse, and that the resultant generation of NCAD-dimers leads to the formation of synaptic contacts in neurons maintained under physiological conditions [68]. 


\section{Plasminogen Activators in the Neurovascular Unit (NVU) under Ischemic Conditions}

Ischemic stroke is a leading cause of mortality and disability in the world [69]. Significantly, plasminogen activators are pivotal for the protection and repair of the NVU that has suffered an ischemic injury. Indeed, while acute cerebral ischemia causes the rapid release of tPA from each cellular compartment of the NVU [70], the abundance and activity of uPA increase only during the recovery stages from the ischemic insult [61]. These data have led to the proposal that while the early release of tPA restores the patency of the occluded blood vessel and has a neuroprotective effect, the delayed release of uPA promotes the repair of the damaged NVU. Below we will review data on the role of tPA and uPA in each component of the NVU under hypoxic/ischemic conditions.

\subsection{Endothelial Cells}

\subsubsection{Tissue-Type Plasminogen Activator}

The effect of hypoxia on the release of tPA from human cerebrovascular endothelial cells has been poorly characterized. However, studies with human saphenous and umbilical veins $[71,72]$ have shown that hypoxia decreases the abundance and activity of tPA in endothelial cells, and that this effect is accompanied by an increase in the expression and activity of PAI-1. Furthermore, in vitro studies with rat brain microvascular endothelial cells indicate that tPA has a harmful effect on endothelial cells exposed to oxygen and glucose deprivation conditions [4,73]. In contrast with these in vitro studies, in vivo observations have revealed an increase in the concentrations of tPA and PAI-1 in the intravascular space of patients suffering an acute ischemic stroke [74], suggesting that endothelial cells release tPA into the intravascular space as an attempt to restore the patency of the occluded blood vessel. This is supported by the observation of complete or nearly complete recovery of neurological function in acute ischemic stroke patients intravascularly treated with recombinant tPA within 3-4.5 h of the onset of symptoms [75,76].

A growing body of experimental evidence indicates a link between plasminogen activation and the immune system. Indeed, while some studies have revealed that plasminogen activators play a role in bradykinin-mediated endothelial cell activation [77], others show that an interaction between plasmin and factor XII increases the permeability of the neurovascular unit in neurodegenerative diseases [78,79]. Importantly, in apparent discrepancy with a proinflammatory role of plasmin, in vivo studies with an animal model of cerebral ischemia suggest that tPA attenuates the activation of the immune response in the neurovascular unit that has suffered an ischemic injury [80].

\subsubsection{Urokinase-Type Plasminogen Activator}

The role of uPA in hypoxic/ischemic cerebral endothelial cells is even less well studied. Indeed, although studies with human umbilical endothelial cells (HUVEC) [81] and human microvascular endothelial cells [82] have revealed that a hypoxia-induced, hypoxiainducible factor (HIF)-mediated increase in UPAR expression in endothelial cells triggers angiogenesis and cell migration [83], the effect of hypoxia on UPA and UPAR expression and function in cerebral endothelial cells has not been characterized. Independently of these considerations, clinical studies indicate that the intravascular administration of recombinant uPA effectively restores the patency of the occluded blood vessel and improves neurological outcome in acute ischemic stroke patients [84,85].

\subsection{Astrocytes}

\subsubsection{Tissue-Type Plasminogen Activator}

As discussed above, tPA is abundantly found in astrocytes [21], and the release of astrocytic tPA has a direct effect on the permeability of the NVU. Indeed, the interaction between tPA, released from perivascular astrocytes in response to the ischemic injury, and the low-density lipoprotein receptor-related protein-1 (LRP-1) found in astrocytic end-feet processes, activates an NF-K-regulated inflammatory response [86] and triggers the detach- 
ment of perivascular astrocytes from the basement membrane, which in turn increases the permeability of the blood-brain barrier, thus causing ischemic cerebral edema [21]. In line with these observations, the intracerebroventricular administration of recombinant tPA induces an LRP-1-mediated increase in the permeability of the NVU [87]. The translational relevance of these observations is underscored by neuroradiological studies showing that the intravenous administration of recombinant tPA to acute ischemic stroke patients also increases the permeability of the blood-brain barrier [88] which is in line with a reported 10 -fold increase in the risk of hemorrhagic complications in recombinant tPA (rtPA)-treated stroke patients [75]. Interestingly, besides its effect on the permeability of the NVU, experimental evidence indicates that multipotent mesenchymal stromal cell-induced tPA activity in astrocytes promotes neurorepair after stroke by facilitating neurite outgrowth in the ischemic area $[27,89]$.

\subsubsection{Urokinase-Type Plasminogen Activator}

The roles of astrocytic uPA and uPAR in the ischemic brain have only recently been studied. Accordingly, it was reported that the binding of uPA released from neurons to uPAR recruited to the astrocytic plasma membrane in response to the ischemic injury, induces astrocytic activation [57]. Ezrin is a protein that regulates the reorganization of the actin cytoskeleton [90] and the formation of microvilli, filopodia and lamellipodia [91]. In the cytosol, ezrin exists in an inactive conformation. However, following its recruitment to the plasma membrane, ezrin is activated by phosphorylation at a conserved Thr567 residue [92]. Ezrin is abundantly found in astrocytic filopodia [93], and its activation is required for the formation of peripheral astrocytic processes [94]. Significantly, uPA induces the expression of ezrin in astrocytes, thus triggering the formation of peripheral astrocytic processes that, upon embracing the pre- and post-synaptic compartments, preserve the integrity of the tripartite synapse that has suffered an ischemic insult [58].

\subsection{Microglia}

\subsubsection{Tissue-Type Plasminogen Activator}

Microglial activation is a key step in a sequence of events that trigger not only cell death but also neurorepair in the ischemic brain [95]. Remarkably, tPA is pivotal for microglial activation [31], and in support of these observations, genetic deficiency of tPA attenuates cerebral ischemia-induced microglial activation [32]. Interestingly, the N-terminal fibronectin type III finger domain of tPA also mediates endotoxin-induced microglial activation, most likely by its interaction with annexin II on the cell membrane [96]. Further work has revealed that LRP-1 mediates the effect of tPA on microglial activation in the ischemic brain [97], and that the resultant downstream activation of latent platelet-derived growth factor-CC (PDGF-CC) increases the permeability of the NVU [98]. Additionally, it was reported that by modulating the release of cytokines, interferon- $\beta$ attenuated the effect of tPA-induced microglial activation on the permeability of the NVU [99].

\subsubsection{Urokinase-Type Plasminogen Activator}

It has been recognized that cultured human microglia express uPAR [100], and that the abundance of this receptor in microglia is greatly increased by treatment with endotoxins. More importantly, experimental studies have shown that uPAR is able to induce microglial activation by a mechanism that always requires uPA [101], but that in some cell lines is mediated by MMP-9 [102]. Strikingly, despite the importance of these observations, the role of uPA/uPAR in cerebral ischemia-induced microglial activation is still poorly understood.

\subsection{Neurons}

\subsubsection{Tissue-Type Plasminogen Activator}

Despite the fact that a large number of studies agree on the fact that hypoxia and ischemia trigger the release of neuronal tPA [70,103-105], there is significant disagreement on the effect that this tPA has on cell survival. Indeed, results from early studies 
showing that mice genetically deficient in $\mathrm{tPA}\left(\mathrm{tPA}^{-/-}\right)$have a significant decrease in the volume of the ischemic lesion following transient occlusion of the middle cerebral artery (tMCAo) $[104,106]$ seeded the idea that tPA has a neurotoxic effect in the ischemic brain. Strikingly, this idea lingered for a long time despite subsequent publications by other groups describing an increase in the volume of the ischemic lesion in $\mathrm{tPA}^{-/-}$mice [106], and either a beneficial [107] or even a lack of effect [108] of rtPA treatment on the volume of the ischemic lesion following tMCAo.

This discrepancy was dramatically brought to the forefront of the scientific discussion by the publication of a National Institute of Neurological Disorders and Stroke (NINDS)led clinical study showing that treatment with recombinant tPA within $3 \mathrm{~h}$ of the onset of symptoms was associated with complete or nearly complete recovery in neurological function in a significant number of acute ischemic stroke patients [75,109], and by the subsequent incorporation of rtPA in the protocols used for the treatment of these patients [110]. Notably, although treatment with rtPA also increases the risk of intracerebral hemorrhage [109] and augments the permeability of the NVU [89], to this date no clinical study has shown a neurotoxic effect caused by rtPA treatment. The translational impact of this disagreement between basic and clinical researchers has been heightened by the observation that, following its intravenous administration, rtPA crosses through the blood-brain barrier and permeates the ischemic tissue [111]. In other words, if findings published by basic researchers are true, then clinicians are treating acute ischemic stroke patients with a neurotoxic agent. For obvious reasons this discrepancy needs to be resolved as it has called into question the clinical translatability of basic science research.

Early studies proposed that tPA mediated excitotoxin-induced neuronal death, which is a pivotal mechanism of cell death in the ischemic brain. Indeed, it was found that genetic deficiency of tPA attenuated kainic acid-induced hippocampal cell death [112] via plasmininduced proteolysis of laminin in the extracellular matrix [113], and that $\mathrm{PAA}^{-/-}$mice were resistant to KA-induced seizures [112]. This study was followed by work from a different group of researchers that measured the volume of the ischemic lesion in rodents injected with NMDA into the striatum and then intravascularly treated with $10 \mathrm{mg} / \mathrm{Kg} / \mathrm{IV}$ of rtPA [114]. These investigators found that rtPA treatment enhanced the harmful excitotoxic effect of NMDA, which was interpreted as another demonstration of a neurotoxic effect of tPA. In contrast, a different group of investigators using a similar experimental paradigm but a different dose of $\mathrm{rtPA}(0.9 \mathrm{mg} / \mathrm{Kg} / \mathrm{IV}$, the same dose used to treat acute ischemic stroke patients), found an opposite effect: a decrease in the volume of the necrotic lesion in rtPA-treated animals [115]. Furthermore, they also found that the damage induced by the intrastrial injection of NMDA was significantly attenuated in mice overexpressing tPA only in neurons. Additionally, it was soon clear that the intracerebral injection of an excitotoxin (kainic acid) caused a transient increase in the activity of tPA in cells of the hippocampal CA1 layer that survived the excitotoxic injury [116], and this was followed by a report indicating that IPA protected hippocampal cells from the harmful effects of the excitotoxic injury [117].

This led a different group of investigators to quantify neuronal survival in cerebral cortical neurons incubated with NMDA in the presence of $0-500 \mathrm{nM}$ of either proteolytically active tPA or a mutant of tPA with an alanine for serine substitution at the active site Ser481 that rendered it unable to catalyze the conversion of plasminogen into plasmin (proteolytically inactive tPA) [115]. These experiments revealed that tPA caused a modest increase in NMDA-induced neuronal death only at doses greater than $100 \mathrm{nM}$, which are not found in in vivo systems, even after the intravenous administration of rtPA. Furthermore, it was discovered that at concentrations found in the ischemic brain, tPA attenuated NMDA-induced neuronal death by a mechanism that did not entail plasmin generation but required the co-receptor function of a member of the low-density lipoprotein receptor (LDLR) family, most likely LRP1. In an attempt to explain these discrepancies, it was proposed that selective activation of NMDA receptors by single-chain but not two-chain tPA is responsible for the neurotoxic effect of tPA [118], and therefore that treatment with 
two-chain tPA is more efficient than single-chain tPA to reduce the volume of the ischemic lesion and promote functional recovery after the experimental induction of an ischemic stroke [119]. Together, these results show that a causal link between tPA and cerebral ischemia- and excitotoxin-induced neuronal death was difficult to establish, as it seemed to depend on the chemical structure and dose of rtPA as well as the specific experimental paradigm used in each report.

The resultant renewed interest of the scientific community to understand the role of neuronal tPA in the ischemic brain led a group of investigators using an in vitro model of oxygen and glucose deprivation (OGD) to discover that treatment with $5 \mathrm{nM}$ of rtPA prevented cell death in cerebral cortical neurons exposed to $55 \mathrm{~min}$ of OGD conditions, and that this effect was mediated by LRP1 and open synaptic NMDA receptors [104]. Remarkably, the detection of a maximal neuroprotective effect within the first three hours after OGD bears a notable resemblance with the maximal neurological recovery observed in acute ischemic stroke patients treated with rtPA within three hours of the onset of symptoms [75]. The obvious lack of a clot in this in vitro system indicated that a mechanism other than thrombolysis mediates tPA's neuroprotective effect, and this possibility was confirmed by the finding that treatment with recombinant tPA after tMCAo also decreased the volume of the ischemic lesion in animals genetically deficient in plasminogen $\left(\mathrm{Plg}^{-/}\right)$. These data indicate that IPA has a neuroprotective effect in the ischemic brain that is not mediated by the generation of plasmin and instead requires the co-receptor function of the NMDAR and a member of the LDLR family.

\subsubsection{Urokinase-Type Plasminogen Activator}

The role of uPA in the ischemic NVU is less well understood. Indeed, early studies with an animal model of permanent cerebral ischemia induced by occluding a distal branch of the middle cerebral artery with a surgical suture showed a decrease in the volume of the ischemic lesion in mice genetically deficient in uPAR [105] but not uPA [120]. Interestingly, using a similar animal model of cerebral ischemia, a different group of investigators detected a large increase in uPA-catalyzed proteolysis $72 \mathrm{~h}$ after the onset of the ischemic injury [121]. This was followed by the observation that the concentrations of uPA in the culture medium of cerebral cortical neurons remained unchanged during $60 \mathrm{~min}$ of exposure to OGD conditions [61].

However, in an unexpected turn of events, it was found that these neurons released large amounts of uPA after they were returned to normoxic conditions. Importantly, this uPA did not seem to have an effect on cell death, as there was no difference in neuronal survival between $\mathrm{Wt}$ and $\mathrm{uPA}^{-/-}$neurons exposed to OGD conditions [61]. The in vivo significance of these observations was supported by the finding that although cerebral ischemia did not have an effect on the abundance of uPA during the acute phase of the ischemic injury, the expression of uPA in the ischemic tissue increased during the recovery period.

The finding that the delayed release of uPA following a hypoxic/ischemic injury did not have an effect on neuronal survival or the volume of the ischemic lesion, led researchers to investigate if uPA plays a role in neurorepair. Noticeably, this possibility was supported by the observation that compared to wild-type (Wt) littermate controls, $\mathrm{uPA}^{-/}$ and $\mathrm{uPAR}^{-/-}$mice had a protracted recovery in neurological function following tMCAo, and that treatment with ruPA or the release of endogenous uPA prompted functional recovery in $\mathrm{Wt}$ and $\mathrm{uPA}^{-/-}$, but not in $\mathrm{uPAR}^{-/-}$mice [60,61].

Further studies showed that the release of uPA promoted the recovery of axonal boutons and post-synaptic terminals disassembled by the ischemic injury. More specifically, it was found that by regulating the expression and activity of GAP-43, neuronal uPA promoted the regeneration of axons damaged by the ischemic injury [122]. Furthermore, by its ability to regulate the expression of ezrin, uPA was able to reorganize the cytoskeleton of the post-synaptic density, prompting the recovery of dendritic spines that disappeared in the earlier stages of the ischemic insult [61]. In line with these observations, in vivo 
studies indicated that intravenous treatment with recombinant uPA $24 \mathrm{~h}$ after the onset of the ischemic injury increased the number of synaptic contacts in the area that surrounds the necrotic core [57].

In summary, the data available to this date indicate that the expression of uPA and UPAR increases in the recovery stages of an ischemic stroke, and suggest that uPA binding to UPAR plays a central role in the process of neurorepair following an acute ischemic injury. These observations are supported by reports from other groups indicating that uPAR modulates peripheral nerve regeneration after a crushed nerve [67], and that genetic deficiency of uPA aggravates the motor deficit and increases neuronal death in an animal model of traumatic brain injury [121].

\section{Plasminogen Activators in Neurodegenerative Disorders}

The concept of neurodegenerative disorders encompasses several clinical entities including Alzheimer's disease (AD), Parkinson's disease (PD) and amyotrophic lateral sclerosis (ALS), all characterized by the progressive decline of neuronal function. Remarkably, a rapidly growing knowledge of the pathophysiology of these disorders has led to two important conclusions. First, that they are not caused by isolated neuronal pathology, but instead that a dysfunctional NVU is a contributory factor in many of them [122,123]; and second, that a dysfunctional plasminogen activating system plays a still poorly understood role in their pathophysiology. Together, the data reviewed below underscore the relevance of the interaction between the plasminogen activating system and neurodegeneration, and how research on this interaction may unveil potential targets for the development of strategies for their prevention and treatment.

\subsection{Plasminogen Activators in Alzheimer's Disease}

AD affects approximately 46.8 million people worldwide, and this number is expected to reach 131.5 million by 2050 [124]. It is a dual proteinopathy, that accounts for almost $60-80 \%$ of all dementias, and is characterized by the extracellular deposition of A $\beta$ 1-40 and 1-42 fibrils in neuritic plaques and intracellular aggregates of hyperphosphorylated tau in neurofibrillary tangles (NFT). Importantly, a substantial number of studies have found that even in the early stages of this disease the NVU is dysfunctional. Accordingly, a long-time accepted neurocentric theory of the genesis of AD has slowly been integrated into a more holistic model that includes all the cellular and non-cellular components of the NVU.

\subsection{Endothelial Cells}

There is ample evidence implicating endothelial cell dysfunction in the pathophysiology of AD. Indeed, virtually all AD patients exhibit endothelial cell degeneration and abnormal thickening of the perivascular basement membrane in zones with A $\beta$ deposition [125]. These morphological changes underlie the reduction in cerebral blood flow, and impaired cerebrovascular reactivity and neurovascular coupling observed even in early stages of the disease [126,127]. Importantly, the few studies published to this date on plasminogen activators and endothelial cells in AD indicate that although A $\beta$ does not have an effect on the release of endothelial tPA [19], deficiency of this plasminogen activator, likely caused by increased PAI-1, underlies the impairment in neurovascular coupling observed in mice expressing the Swedish mutation of the amyloid precursor protein (APP; $\operatorname{tg} 2576)$ [128]. It has also been postulated that plasminogen derived from the intravascular space causes an inflammatory response and $A \beta$ deposition. More specifically, it has been reported that depletion of plasminogen in the intravascular space attenuates microglial activation and improves AD pathology in mice transgenic for human APP/Presinilin 1 with five early-onset familial AD mutations [78]. In contrast with these studies, the role of $\mathrm{uPA}$ in endothelial cell dysfunction in AD has been addressed by fewer investigators. However, it has been reported that $A \beta$ induces the expression of $\mathrm{uPA}$ in cultured human cerebrovascular smooth muscle cells [129], and that LRP1 in endothelial cells regulates 
the efflux of $A \beta$ into the intravascular space [130]. The translational relevance of these observations, performed in the murine brain, should be understood in the light of studies indicating that human brain endothelial cells do not express LRP1 [131].

\subsection{Astrocytes}

Several studies have reported an association between early astrocytic activation [132] and poor prognosis in advanced phases of this disease [133]. Interestingly, this process seems to affect only a sub-population of astrocytes with an increased abundance of aquaporin-4 in their end-feet processes [134]. This is of special interest, because the interaction between astrocytic end-feet processes and endothelial cells modulates the permeability of the NVU [135]. In line with these observations, in vitro and in vivo studies have revealed an increase in the permeability of the NVU in different animal models of $\mathrm{AD}$ [129] and in the brain of AD patients [136]. Finally, astrocytes are tightly associated with $A \beta$ catabolism, and these cells display an abnormal response upon exposure to $A \beta$ [137]. Strikingly, no studies have directly addressed the specific role of astrocytic tPA and uPA in the pathogenesis of Alzheimer's disease.

\subsection{Microglia}

Microglial activation in the brain of AD patients [138] has been linked to the triggering of a neuroinflammatory response that promotes $A \beta$-containing plaque formation and neuronal degeneration [139]. However, more recent studies have revealed that microglial activation in $\mathrm{AD}$ is a heterogenous process, and in line with these observations, specific and well-differentiated subpopulations of microglia also seem to have a protective effect in the brain of $\mathrm{AD}$ patients [140]. Furthermore, it has been reported that the plasminogen activating system modulates the activation of microglia in $\mathrm{AD} \mathrm{[141]} \mathrm{and} \mathrm{that} \mathrm{treatment}$ with rtPA triggers the activation of the above-mentioned neuroprotective microglial phenotype [142]. In contrast, the role of uPA in microglial activation in AD has been less well studied. However, it has been reported that $\mathrm{A} \beta$-treated human microglia upregulate uPA and UPAR [143] and that uPAR is a marker of microglial activation in the brain of AD patients [144].

\subsection{Neurons}

The amyloid hypothesis of $\mathrm{AD}$ is a neurocentric model in which $\mathrm{A} \beta$ deposition leads to progressive tau hyperphosphorylation, synaptic dysfunction and neuronal loss. However, despite its importance and long-time acceptance, a growing body of experimental evidence suggests that not only neurons, but all cellular and non-cellular elements of the NVU, play key roles in the pathogenesis of this disease [145]. Independently of these considerations, knowledge gathered over the last 3 decades has resulted in a better understanding of the biochemical process that leads to the production and accumulation of $A \beta$. More specifically, the proteolytic processing of APP by $\alpha$-secretase on the cell membrane generates soluble $\mathrm{APP} \alpha$, which has been implicated in neuronal plasticity and synaptogenesis [146]. However, those APP molecules that are not processed by $\alpha$-secretase are endocytosed and cleaved by $\beta$-secretase 1 (BACE1) and $\gamma$-secretase to generate A $\beta 1-40$ and 1-42 peptides [147-149], which have a harmful effect on cell survival and synaptic structure and function $[150,151]$. Inasmuch as our understanding of this process has grown, it has led to the discovery of different therapeutic strategies to minimize $A \beta$ deposition that have been successfully tested in animal models of AD [152], but unsuccessful [153] or only partially effective in AD patients [154].

The last three decades of research on the role of the plasminogen activating system in the pathophysiology of AD have focused almost exclusively on the ability of tPA and uPA to cleave A $\beta$ deposits. However, recent studies have also discovered a role for uPA in the pathogenesis of synaptic dysfunction in $\mathrm{AD}$ that does not require the conversion of plasminogen into plasmin. 


\subsubsection{Plasminogen Activators and the Formation of $A \beta$ Deposits}

A role for plasminogen activators in the pathogenesis of AD was suggested by in vitro studies showing that plasmin triggers $\alpha$-secretase-induced cleavage of $A \beta$ in lipid rafts [155] and cleaves insoluble $A \beta$ fibrils $[156,157]$. This was followed by work revealing a reduction in the expression and activity of plasmin in AD brains [158], most likely due to a decrease in IPA activity [157]. These observations were contested by a different group of investigators that detected normal concentrations of plasminogen and plasmin in the brains of AD patients [159], and postulated that the reported decrease in plasmin was actually due to the disruption of lipid rafts by abnormal cholesterol metabolism in the neuronal membrane [160].

Most of the studies on the role of plasminogen activators on the formation of $A \beta$ deposits have been performed with tPA. Hence, it has been found that insoluble A $\beta$ activates tPA [161] and increases the expression of tPA mRNA in cerebral cortical neurons, purportedly as an attempt to trigger plasmin-induced cleavage of extracellular insoluble $A \beta$-containing plaques [158]. In discrepancy with these studies, in vivo studies with mouse models of $A D$ have revealed that chronic elevation of $A \beta$ actually decreases tPA activity by enhancing the inhibitory effect of PAI- 1 on tPA, and that the intracerebral injection of $A \beta$ causes neuronal degeneration in animals genetically deficient in either tPA or plasminogen [162].

More specifically, the expression of PAI-1 is increased in the cerebrospinal fluid [163] and the brains of AD patients [164]. The clinical relevance of these observations is underscored by experimental work indicating that the genetic deletion of PAI- 1 in the brain of a murine model of $\mathrm{AD}$ reduces the deposition of $\mathrm{A} \beta$ by increasing tPA-induced plasminmediated cleavage of $A \beta$-containing plaques [164]. Together, these data have led to the proposal of a model in which increased PAI-1 activity in the brain of AD patients abrogates tPA-induced plasmin-triggered cleavage of $A \beta$ deposits. In seeming contradiction with a protective role of tPA in $\mathrm{AD}$, other studies have shown that this plasminogen activator actually mediates the neurotoxic effect of $A \beta$ via ERK $\frac{1}{2}$ activation [165]. The role of uPA on the formation of $A \beta$ deposits has been less well studied. Nevertheless, it has been reported that $A \beta$ increases the abundance of uPA mRNA [156], and that as described for tPA, uPA also induces plasmin-mediated cleavage of insoluble $A \beta$-containing extracellular plaques [166].

\subsubsection{Role of Plasminogen Activators in Synaptic Dysfunction in AD}

The idea that the extracellular accumulation of insoluble $A \beta$ peptides is the cause of the cognitive decline observed in $\mathrm{AD}$ patients [167] has been challenged by neuropathological and clinical studies indicating that the development of cognitive deficits in these individuals correlates with abnormalities in synaptic structure and function more than with the number of tangles and insoluble $\mathrm{A} \beta$-containing plaques $[168,169]$. This concept is of significant translational importance, because synaptic dysfunction is an early event in the pathogenesis of $\mathrm{AD}$ that is amenable to therapeutic interventions to prevent its development.

Our knowledge of the synaptic role of $A \beta$ has increased significantly during the last 30 years. Hence, we know that the production of $A \beta$ increases during neuronal activity [150], and that while at low concentrations, soluble $A \beta$ induces presynaptic facilitation, at high concentrations triggers post-synaptic depression [170] by decreasing the abundance of glutamatergic receptors in the postsynaptic density $[161,171]$ and enhances the excitotoxic effect of glutamate by blocking its reuptake from the synaptic cleft [172]. Additionally, high concentrations of $A \beta$ impair long-term potentiation (LTP) and enhance long-term depression (LTD) by blocking $\alpha$-amino-3-hydroxy-5-methyl-4-isoxazolepropionic acid (AMPA) and NMDA receptor function [173], and augment the excitotoxic effect of glutamate by blocking its reuptake from the synaptic cleft [172]. Importantly, increased soluble A $\beta$ has been linked to synaptic depression and the disruption of neuronal network activity in the brains of AD patients [171]. Furthermore, it has been reported that uPA antagonizes the 
harmful effect of $A \beta$ on synaptic structure and function by a mechanism independent of its ability to trigger proteolytic cleavage of $A \beta$-containing plaques [68].

Recent studies have shown that cleavage of $A \beta$-containing plaques is not the only role of $\mathrm{UPA}$ in AD brains. Hence, it has been found that the expression of uPA, but not of its receptor (UPAR), is decreased in the synapses of AD patients and 5XFAD mice (express human APP with the Swedish (KM670/671NL), Florida (I716V) and London (V717I) mutations together with a mutant presenilin 1 (M146L, L286V) under the control of the murine Thy- 1 promoter), by the ability of $\mathrm{A} \beta$ to halt the transcription of uPA mRNA in neurons but not in astrocytes [68]. The translational importance of these findings is supported by observations indicating that treatment with recombinant uPA abrogates the harmful effect of soluble $A \beta$ on synaptic structure and function, via its ability to induce the expression of neuronal cadherin (NCAD). Remarkably, in contrast with the reported effect of tPA and uPA on the proteolytic cleavage of $A \beta$-containing plaques, the effect of uPA on the synapses of $\mathrm{AD}$ patients and animal models of $\mathrm{AD}$ does not require the generation of plasmin.

\subsubsection{Plasminogen Activators, Physical Activity and Alzheimer's Disease}

Physical activity has a direct effect on the expression and activity of components of the plasminogen activating system. More specifically, 6 months of intensive physical activity increase the intravascular concentration of tPA and uPA, and this effect is accompanied by a substantial decrease in the levels of PAI-1 $[15,174]$. These observations are of significant importance when interpreted in the context of studies showing that physical activity decreases the risk of $\mathrm{AD}$ [175] and improves the attention span, memory and executive functioning of healthy individuals [176]. Thus, it is tempting to postulate that plasminogen activators mediate the protective effect of exercise on cognitive function and the risk of developing AD. However, although scientifically plausible, to this date there are no data to support this hypothesis.

\subsection{Plasminogen Activators in Parkinson's Disease}

Parkinsonism is a clinical syndrome characterized by bradykinesia, resting tremor, rigidity and postural and gait impairment. Most cases of parkinsonism are caused by Parkinson's disease (PD), which is a neurodegenerative disease that affects $3 \%$ of the population older than 65 years of age [177]. The neuropathological hallmarks of this disease are the loss of dopamine-containing neurons in the substantia nigra and the presence of $\alpha$-synuclein-containing intracellular inclusions. The extracellular levels of $\alpha$-synuclein depend not only on its release from neurons, but also on its removal by proteolytic degradation. It is unclear if $\alpha$-synuclein induces the expression or activity of tPA or uPA. However, plasmin cleaves and degrades $\alpha$-synuclein, and $\alpha$-synuclein upregulates PAI-1 [178]. It has thus been proposed that an excess of PAI- 1 in the brains of PD patients prevents plasmin-induced clearance of $\alpha$-synuclein aggregates [179]. The translational relevance of these findings is supported by the fact that increased levels of PAI-1 have been linked to a worse clinical prognosis in PD patients [180]. Despite the importance of these observations, to this date it is unclear if tPA- or uPA-catalyzed plasmin generation plays a role in the pathogenesis of this disease.

\subsection{Plasminogen Activators in Amyotrophic Lateral Sclerosis (ALS)}

Amyotrophic lateral sclerosis (ALS) is a motor neuron disease characterized by a progressive decline in motor function caused by weakness and spasticity without sensory loss. Knowledge on the role of plasminogen activators in the pathogenesis of ALS is still in its earlier stages. However, it has been reported that plasminogen from ALS patients, and recombinant tPA and plasmin, induce motoneuron degeneration in BALB/c mice [181]. Likewise, experimental work with G93 mice (with a SOD1 mutation linked to familial ALS) and samples from ALS patients revealed that the abundance of uPAR increased in the ventral horn of the spinal cord of ALS patients and G93 mice, along with enhanced 
uPA-dependent plasminogen activation in advanced stages of this disease. Remarkably, treatment with an inhibitor of uPA prolonged survival in these animals [182].

Author Contributions: Writing, editing and funding acquisition, M.Y.; writing and investigation, Y.W.; writing - original draft preparation, C.M.-J. All authors have read and agreed to the published version of the manuscript.

Funding: This research was funded in part by National Institutes of Health Grant NS-NS091201 (to M.Y.) and VA MERIT Award IO1BX003441 (to M.Y.).

Data Availability Statement: Not Applicable.

Conflicts of Interest: The authors declare no conflict of interest.

\section{References}

1. Raum, D.; Marcus, D.; Alper, C.A.; Levey, R.; Taylor, P.D.; Starzl, T.E. Synthesis of Human Plasminogen by the Liver. Science 1980, 208, 1036-1037. [CrossRef] [PubMed]

2. Petersen, T.E.; Martzen, M.R.; Ichinose, A.; Davie, E.W. Characterization of the Gene for Human Plasminogen, A Key Proenzyme in the Fibrinolytic System. J. Biol. Chem. 1990, 265, 6104-6111. [CrossRef]

3. Das, R.; Pluskota, E.; Plow, E.F. Plasminogen and Its Receptors as Regulators of Cardiovascular Inflammatory Responses. Trends Cardiovasc. Med. 2010, 20, 120-124. [CrossRef] [PubMed]

4. Gong, Y.; Kim, S.-O.; Felez, J.; Grella, D.K.; Castellino, F.J; Miles, L.A. Conversion of Glu-Plasminogen to Lys-Plasminogen Is Necessary for Optimal Stimulation of Plasminogen Activation on the Endothelial Cell Surface. J. Biol. Chem. 2001, 276, 19078-19083. [CrossRef]

5. Lawrence, D.; Strandberg, L.; Grundström, T.; Ny, T. Purification of Active Human Plasminogen Activator Inhibitor 1 from Escherichia Coli. Comparison with Natural and Recombinant Forms Purified from Eucaryotic Cells. Eur. J. Biochem. 1989, 186, 523-533. [CrossRef]

6. Draxler, D.F.; Sashindranath, M.; Medcalf, R.L. Plasmin: A Modulator of Immune Function. Semin. Thromb. Hemost. 2016, 43, 143-153. [CrossRef]

7. Muoio, V.; Persson, P.B.; Sendeski, M.M. The Neurovascular Unit-Concept Review. Acta Physiol. 2014, 210, 790-798. [CrossRef]

8. Pennica, D.; Holmes, W.E.; . Kohr, W.J; Harkins, R.N.; Vehar, G.A.; Ward, C.A.; Bennett, W.F.; Yelverton, E.; Seeburg, P.H.; Heyneker, H.L.; et al. Cloning and Expression of Human Tissue-Type Plasminogen-Activator Cdna in Escherichia-Coli. Nature 1983, 301, 214-221. [CrossRef]

9. Yepes, M.; Roussel, B.D.; Ali, C.; Vivien, D. Tissue-Type Plasminogen Activator in the Ischemic Brain: More than a Thrombolytic. Trends Neurosci. 2009, 32, 48-55. [CrossRef]

10. Kim, J.A.; Tran, N.D.; Wang, S.-J.; Fisher, M.J. Astrocyte Regulation of Human Brain Capillary Endothelial Fibrinolysis. Thromb. Res. 2003, 112, 159-165. [CrossRef]

11. Huber, D.; Cramer, E.M.; Kaufmann, J.E.; Meda, P.; Massé, J.-M.; Kruithof, E.K.O.; Vischer, U.M. Tissue-Type Plasminogen Activator (t-PA) is Stored in Weibel-Palade Bodies in Human Endothelial Cells Both in Vitro and in Vivo. Blood 2002, 99, 3637-3645. [CrossRef]

12. Hanss, M.; Collen, D. Secretion of Tissue-Type Plasminogen Activator and Plasminogen Activator Inhibitor by Cultured Human Endothelial Cells: Modulation by Thrombin, Endotoxin, and Histamine. J. Lab. Clin. Med. 1987, 109, 97-104.

13. Pepper, M.S.; Rosnoblet, C.; Di Sanza, C.; Kruithof, E.K. Synergistic Induction of t-PA by VASCULAR endothelial Growth Factor and Basic Fibroblast Growth Factor and Localization of t-PA to Weibel-Palade Bodies in Bovine Microvascular Endothelial Cells. Thromb. Haemost. 2001, 86, 702-709.

14. Kawai, Y.; Matsumoto, Y.; Watanabe, K.; Yamamoto, H.; Satoh, K.; Murata, M.; Handa, M.; Ikeda, Y. Hemodynamic Forces Modulate the Effects of Cytokines on Fibrinolytic Activity of Endothelial Cells. Blood 1996, 87, 2314-2321. [CrossRef] [PubMed]

15. Chandler, W.L.; Levy, W.C.; Stratton, J.R. The Circulatory Regulation of TPA and UPA Secretion, Clearance, and Inhibition During Exercise and During the Infusion of Isoproterenol and Phenylephrine. Circulation 1995, 92, 2984-2994. [CrossRef]

16. Stein, C.; Brown, N.; E Vaughan, D.; Lang, C.C.; Wood, A.J. Regulation of Local Tissue-Type Plasminogen Activator Release by Endothelium-Dependent and Endothelium-Independent Agonists in Human Vasculature. J. Am. Coll. Cardiol. 1998, 32, 117-122. [CrossRef]

17. Levin, E.G.; Del Zoppo, G.J. Localization of Tissue Plasminogen Activator in the Endothelium of a Limited Number of Vessels. Am. J. Pathol. 1994, 144, 855-861.

18. Yang, F.; Liu, S.; Wang, S.-J.; Yu, C.; Paganini-Hill, A.; Fisher, M.J. Tissue Plasminogen Activator Expression and Barrier Properties of Human Brain Microvascular Endothelial Cells. Cell Physiol. Biochem. 2011, 28, 631-638. [CrossRef] [PubMed]

19. Cho, M.-K.; Sun, E.-S.; Kim, Y.-H. Zinc-Triggered Induction of Tissue Plasminogen Activator and Plasminogen in Endothelial Cells and Pericytes. Exp. Neurobiol. 2013, 22, 315-321. [CrossRef] [PubMed]

20. Kim, J.A.; Tran, N.D.; Li, Z.; Yang, F.; Zhou, W.; Fisher, M.J. Brain Endothelial Hemostasis Regulation by Pericytes. J. Cereb. Blood Flow Metab. 2006, 26, 209-217. [CrossRef] 
21. Polavarapu, R.; Gongora, M.C.; Yi, H.; Ranganthan, S.; Lawrence, D.A.; Strickland, D.; Yepes, M. Tissue-Type Plasminogen Activator-Mediated Shedding of Astrocytic Low-Density Lipoprotein Receptor-Related Protein Increases the Permeability of the Neurovascular Unit. Blood 2006, 109, 3270-3278. [CrossRef]

22. Tang, H.; Fu, W.Y.; Ip, N.Y. Altered Expression of Tissue-Type Plasminogen Activator and Type 1 Inhibitor in Astrocytes of Mouse Cortex Following Scratch Injury in Culture. Neurosci. Lett. 2000, 285, 143-146. [CrossRef]

23. Zhang, C.; An, J.; Haile, W.B.; Echeverry, R.; Strickland, D.K.; Yepes, M. Microglial Low-Density Lipoprotein Receptor-Related Protein 1 Mediates the Effect of Tissue-Type Plasminogen Activator on Matrix Metalloproteinase-9 Activity in the Ischemic Brain. J. Cereb. Blood Flow Metab. 2009, 29, 1946-1954. [CrossRef]

24. Hu, K.; Yang, J.; Tanaka, S.; Gonias, S.L.; Mars, W.M.; Liu, Y. Tissue-Type Plasminogen Activator Acts as a Cytokine That Triggers Intracellular Signal Transduction and Induces Matrix Metalloproteinase-9 Gene Expression. J. Biol. Chem. 2006, 281, 2120-2127. [CrossRef]

25. Polavarapu, R.; Gongora, M.C.; Winkles, J.A.; Yepes, M. Tumor Necrosis Factor-Like Weak Inducer of Apoptosis Increases the Permeability of the Neurovascular Unit through Nuclear Factor-Kappa B Pathway Activation. J. Neurosci. 2005, 25, 10094-10100. [CrossRef]

26. Lin, L.; Wu, C.; Hu, K. Tissue Plasminogen Activator Activates NF-kappaB through a Pathway Involving Annexin A2/CD11b and Integrin-Linked Kinase. J. Am. Soc. Nephrol. 2012, 23, 1329-1338. [CrossRef]

27. Xin, H.; Li, Y.; Shen, L.H.; Liu, X.; Hozeska-Solgot, A.; Zhang, R.L.; Zhang, Z.G.; Chopp, M. Multipotent Mesenchymal Stromal Cells Increase tPA Expression and Concomitantly Decrease PAI-1 Expression in Astrocytes through the Sonic Hedgehog Signaling Pathway after Stroke (In Vitro Study). J. Cereb. Blood Flow Metab. 2011, 31, 2181-2188. [CrossRef]

28. Cassé, F.; Bardou, I.; Danglot, L.; Briens, A.; Montagne, A.; Parcq, J.; Alahari, A.; Galli, T.; Vivien, D.; Docagne, F. Glutamate Controls tPA Recycling by Astrocytes, Which in Turn Influences Glutamatergic Signals. J. Neurosci. 2012, 32, 5186-5199. [CrossRef]

29. Vincent, V.A.; Löwik, C.W.; Verheijen, J.H.; De Bart, A.C.; Tilders, F.J.; Van Dam, A. Role of Astrocyte-Derived Tissue-Type Plasminogen Activator in the Regulation of Endotoxin-Stimulated Nitric Oxide Production by Microglial Cells. Glia 1998, 22, 130-137. [CrossRef]

30. Siao, C.H.-J.; Susana, R.F.; Stella, E.T. Cell Type-Specific Roles for Tissue Plasminogen Activator Released by Neurons or Microglia after Excitotoxic Injury. J. Neurosci. 2003, 23, 3224-3242. [CrossRef]

31. Siao, C.J.; Tsirka, S.E. Tissue Plasminogen Activator Mediates Microglial Activation via its Finger Domain through Annexin II. J. Neurosci. 2002, 22, 3352-3358. [CrossRef]

32. Rogove, A.D.; Siao, C.; Keyt, B.; Strickland, S.; E Tsirka, S. Activation of Microglia Reveals a Non-Proteolytic Cytokine Function for Tissue Plasminogen Activator in the Central Nervous System. J. Cell Sci. 1999, 112, 4007-4016.

33. Flavin, M.P.; Zhao, G. Tissue Plasminogen Activator Protects Hippocampal Neurons from Oxygen-Glucose Deprivation Injury. J. Neurosci. Res. 2001, 63, 388-394. [CrossRef]

34. Krystosek, A.; Seeds, N.W. Plasminogen Activator Release at the Neuronal Growth Cone. Science 1981, 213, 1532-1534. [CrossRef]

35. Seeds, N.W.; Basham, M.E.; Haffke, S.P. Neuronal Migration is Retarded in Mice Lacking the Tissue Plasminogen Activator Gene. Proc. Natl. Acad. Sci. USA 1999, 96, 14118-14123. [CrossRef]

36. Lee, S.H.; Ko, H.M.; Kwon, K.J.; Lee, J.; Han, S.H.; Han, D.W.; Cheong, J.H.; Ryu, J.H.; Shin, C.Y. tPA Regulates Neurite Outgrowth by Phosphorylation of LRP5/6 in Neural Progenitor Cells. Mol. Neurobiol. 2014, 49, 199-215. [CrossRef]

37. Muller, C.M.; Griesinger, C.B. Tissue Plasminogen Activator Mediates Reverse Occlusion Plasticity in Visual Cortex. Nat. Neurosci. 1998, 1, 47-53. [CrossRef] [PubMed]

38. Shen, L.H.; Xin, H.; Li, Y.; Zhang, R.L.; Cui, Y.; Zhang, L.; Lü, M.; Zhang, Z.G.; Chopp, M. Endogenous Tissue Plasminogen Activator Mediates Bone Marrow Stromal Cell-Induced Neurite Remodeling after Stroke in Mice. Stroke 2011, 42, 459-464. [CrossRef] [PubMed]

39. Sappino, A.P.; Madani, R.; Huarte, J.; Belin, D.; Kiss, J.Z.; Wohlwend, A.; Vassalli, J.D. Extracellular Proteolysis in the Adult Murine Brain. J. Clin. Investig. 1993, 92, 679-685. [CrossRef]

40. Nicole, O.; Docagne, F.; Ali, C.; Margaill, I.; Carmeliet, P.; MacKenzie, E.T.; Vivien, D.; Buisson, A. The Proteolytic Activity of Tissue-Plasminogen Activator Enhances NMDA Receptor-Mediated Signaling. Nat. Med. 2001, 7, 59-64. [CrossRef] [PubMed]

41. Samson, A.L.; Medcalf, R.L. Tissue-Type Plasminogen Activator: A Multifaceted Modulator of Neurotransmission and Synaptic Plasticity. Neuron 2006, 50, 673-678. [CrossRef] [PubMed]

42. Qian, Z.; Gilbert, M.E.; Colicos, M.A.; Kandel, E.R.; Kuhl, D. Tissue-Plasminogen Activator is Induced as an Immediate-Early Gene during Seizure, Kindling and Long-Term Potentiation. Nature 1993, 361, 453-457. [CrossRef] [PubMed]

43. Seeds, N.W.; Basham, M.E.; Ferguson, J.E. Absence of Tissue Plasminogen Activator Gene or Activity Impairs Mouse Cerebellar Motor Learning. J. Neurosci. 2003, 23, 7368-7375. [CrossRef] [PubMed]

44. Seeds, N.W.; Williams, B.L.; Bickford, P.C. Tissue Plasminogen Activator Induction in Purkinje Neurons after Cerebellar Motor Learning. Science 1995, 270, 1992-1994. [CrossRef]

45. Pawlak, R.; Magarinos, A.M.; Melchor, J.; McEwen, B.; Strickland, S. Tissue Plasminogen Activator in the Amygdala is Critical for Stress-Induced Anxiety-Like Behavior. Nat. Neurosci. 2003, 6, 168-174. [CrossRef]

46. Stepanova, V.V.; Tkachuk, V.A. Urokinase as a Multidomain Protein and Polyfunctional Cell Regulator. Biochemistry 2002, $67,109-118$. 
47. Danø, K.; Andreasen, P.; Grøndahl-Hansen, J.; Kristensen, P.; Nielsen, L.; Skriver, L. Plasminogen Activators, Tissue Degradation, and Cancer. Adv. Cancer Res. 1985, 44, 139-266.

48. Stoppelli, M.; Tacchetti, C.; Cubellis, M.; Corti, A.; Hearings, V.J.; Cassani, G.; Appella, E.; Blasi, F. Autocrine Saturation of Pro-urokinase Receptors on Human A431 Cells. Cell 1986, 45, 675-684. [CrossRef]

49. Cubellis, M.V.; Wun, T.C.; Blasi, F. Receptor-Mediated Internalization and Degradation of Urokinase is Caused by Its Specific Inhibitor PAI-1. EMBO J. 1990, 9, 1079-1085. [CrossRef]

50. Cao, D.J.; Guo, Y.L.; Colman, R.W. Urokinase-Type Plasminogen Activator Receptor is Involved in Mediating the Apoptotic Effect of Cleaved High Molecular Weight Kininogen in Human Endothelial Cells. Circ. Res. 2004, 94, 1227-1234. [CrossRef]

51. Breuss, J.M.; Uhrin, P. VEGF-Initiated Angiogenesis and the uPA/uPAR System. Cell Adh. Migr. 2012, 6, 535-615. [CrossRef]

52. Prager, G.W.; Breuss, J.M.; Steurer, S.; Mihaly, J.; Binder, B.R. Vascular Endothelial Growth Factor (VEGF) Induces Rapid Prourokinase (pro-uPA) Activation on the Surface of Endothelial Cells. Blood 2004, 103, 955-962. [CrossRef]

53. Pepper, M.S.; Vassalli, J.D.; Montesano, R.; Orci, L. Urokinase-Type Plasminogen Activator is Induced in Migrating Capillary Endothelial Cells. J. Cell Biol. 1987, 105, 2535-2541. [CrossRef]

54. Stie, J.; Fox, D. Induction of Brain Microvascular Endothelial Cell Urokinase Expression by Cryptococcus Neoformans Facilitates Blood-Brain Barrier Invasion. PLoS ONE 2012, 7, e49402. [CrossRef]

55. Benton, R.L.; Maddie, M.A.; Dincman, T.A.; Hagg, T.; Whittemore, S.R. Transcriptional Activation of Endothelial Cells by TGFbeta Coincides with Acute Microvascular Plasticity Following Focal Spinal Cord Ischaemia/Reperfusion Injury. ASN Neuro. 2009, 1, AN20090008. [CrossRef]

56. Yamamoto, M.; Sawaya, R.; Mohanam, S.; Bindal, A.K.; Bruner, J.M.; Oka, K.; Rao, V.H.; Tomonaga, M.; Nicolson, G.L.; Rao, J.S. Expression and Localization of Urokinase-Type Plasminogen Activator in Human Astrocytomas in Vivo. Cancer Res. 1994, $54,3656-3661$.

57. Diaz, A.; Merino, P.; Manrique, L.G.; Ospina, J.P.; Cheng, L.; Wu, F.; Jeanneret, V.; Yepes, M. A Cross-talk Between Neuronal Urokinase-type Plasminogen Activator (uPA) and Astrocytic uPA Receptor (uPAR) Promotes Astrocytic Activation and Synaptic Recovery in the Ischemic Brain. J. Neurosci. 2017, 37, 10310-10322. [CrossRef]

58. Diaz, A.; Merino, P.; Manrique, L.G.; Cheng, L.; Yepes, M. Urokinase-Type Plasminogen Activator (uPA) Protects the Tripartite Synapse in the Ischemic Brain via Ezrin-Mediated Formation of Peripheral Astrocytic Processes. J. Cereb. Blood Flow Metab. 2018, 39, 2157-2171. [CrossRef]

59. Rudlin, C.R. A Three-Dimensional Representation of Linear Growth and Skeletal Maturation. Acta. Paediatr. Scand. Suppl. 1989, 356, 46-50. [CrossRef]

60. Merino, P.; Diaz, A.; Jeanneret, V.; Wu, F.; Torre, E.; Cheng, L.; Yepes, M. Urokinase-Type Plasminogen Activator (uPA) Binding to the uPA Receptor (uPAR) Promotes Axonal Regeneration in the Central Nervous System. J. Biol. Chem. 2017, 292, 2741-2753. [CrossRef]

61. Wu, F.; Catano, M.; Echeverry, R.; Torre, E.; Haile, W.B.; An, J.; Chen, C.; Cheng, L.; Nicholson, A.; Tong, F.C.; et al. Urokinase-Type Plasminogen Activator Promotes Dendritic Spine Recovery and Improves Neurological Outcome Following Ischemic Stroke. J. Neurosci. 2014, 34, 14219-14232. [CrossRef] [PubMed]

62. Cho, E.; Lee, K.J.; Seo, J.-W.; Byun, C.J.; Chung, S.-J.; Suh, D.C.; Carmeliet, P.; Koh, J.-Y.; Kim, J.S.; Lee, J.-Y. Neuroprotection by Urokinase Plasminogen Activator in the Hippocampus. Neurobiol. Dis. 2012, 46, 215-224. [CrossRef] [PubMed]

63. Lino, N.; Fiore, L.; Rapacioli, M.; Teruel, L.; Flores, V.; Scicolone, G.; Sánchez, V. uPA-uPAR Molecular Complex is Involved in Cell Signaling during Neuronal Migration and Neuritogenesis. Dev. Dyn. 2014, 243, 676-689. [CrossRef] [PubMed]

64. Farias-Eisner, R.; Vician, L.; Silver, A.; Reddy, S.; Rabbani, S.A.; Herschman, H.R. The Urokinase Plasminogen Activator Receptor (UPAR) is Preferentially Induced by Nerve Growth Factor in PC12 Pheochromocytoma Cells and is Required for NGF-Driven Differentiation. J. Neurosci. 2000, 20, 230-239. [CrossRef]

65. Gilder, A.S.; Jones, K.A.; Hu, J.; Wang, L.; Chen, C.C.; Carter, B.S.; Gonias, S.L. Soluble Urokinase Receptor Is Released Selectively by Glioblastoma Cells That Express Epidermal Growth Factor Receptor Variant III and Promotes Tumor Cell Migration and Invasion. J. Biol. Chem. 2015, 2902, 14798-14809. [CrossRef]

66. Semina, E.; Rubina, K.; Sysoeva, V.; Rysenkova, K.; Klimovich, P.; Plekhanova, O.; Tkachuk, V. Urokinase and Urokinase Receptor Participate in Regulation of Neuronal Migration, Axon Growth and Branching. Eur. J. Cell Biol. 2016, 95, 295-310. [CrossRef]

67. Rivellini, C.; Dina, G.; Porrello, E.; Cerri, F.; Scarlato, M.; Domi, T.; Ungaro, D.; Del Carro, U.; Bolino, A.; Quattrini, A.; et al. Urokinase Plasminogen Receptor and the Fibrinolytic Complex Play a Role in Nerve Repair after Nerve Crush in Mice, and in Human Neuropathies. PLoS ONE 2012, 7, e32059. [CrossRef]

68. Diaz, A.; Merino, P.; Guo, J.D.; Yepes, M.A.; McCann, P.; Katta, T.; Tong, E.M.; Torre, E.; Rangaraju, S.; Yepes, M. Urokinase-Type Plasminogen Activator Protects Cerebral Cortical Neurons from Soluble Abeta-Induced Synaptic Damage. J. Neurosci. 2020, 40, 4251-4263. [CrossRef]

69. Feigin, V.L.; Norrving, B.; Mensah, G.A. Global Burden of Stroke. Circ. Res. 2017, 120, 439-448. [CrossRef]

70. Yepes, M.; Sandkvist, M.; Wong, M.K.; Coleman, T.A.; Smith, E.; Cohan, S.L.; Lawrence, D.A. Neuroserpin Reduces Cerebral Infarct Volume and Protects Neurons from Ischemia-Induced Apoptosis. Blood 2000, 96, 569-576. [CrossRef]

71. Rossetti, L.; Hu, M. Skeletal Muscle Glycogenolysis is More Sensitive to Insulin than is Glucose Transport/Phosphorylation. Relation to the Insulin-Mediated Inhibition of Hepatic Glucose Production. J. Clin. Investig. 1993, 92, 2963-2974. [CrossRef] 
72. Gris, J.; Schved, J.; Brun, S.; Brunschwig, C.; Petris, I.; Lassonnery, M.; Martinez, P.; Sarlat, C. Venous Occlusion and Chronic Cigarette Smoking: Dose-Dependent Decrease in the Measurable Release of Tissue-Type Plasminogen Activator and Von Willebrand Factor. Atherosclerosis 1991, 91, 247-255. [CrossRef]

73. Gong, P.; Li, M.; Zou, C.; Tian, Q.; Xu, Z. Tissue Plasminogen Activator Causes Brain Microvascular Endothelial Cell Injury After Oxygen Glucose Deprivation by Inhibiting Sonic Hedgehog Signaling. Neurochem. Res. 2019, 44, 441-449. [CrossRef]

74. Lindgren, A.; Lindoff, C.; Norrving, B.; Åstedt, B.; Johansson, B.B. Tissue Plasminogen Activator and Plasminogen Activator Inhibitor-1 in Stroke Patients. Stroke 1996, 27, 1066-1071. [CrossRef]

75. The National Institute of Neurological Disorders and Stroke rt-PA Stroke Study Group. Stroke rt. Tissue Plasminogen Activator for Acute Ischemic Stroke. N. Engl. J. Med. 1995, 333, 1581-1587. [CrossRef]

76. Hacke, W.; Kaste, M.; Bluhmki, E.; Brozman, M.; Dávalos, A.; Guidetti, D.; Larrue, V.; Lees, K.R.; Medeghri, Z.; Machnig, T.; et al. Thrombolysis with Alteplase 3 to 4.5 Hours after Acute Ischemic Stroke. N. Engl. J. Med. 2008, 359, 1317-1329. [CrossRef]

77. Van Geffen, M.; Cugno, M.; Lap, P.; Loof, A.; Cicardi, M.; Van Heerde, W. Alterations of Coagulation and Fibrinolysis in Patients with Angioedema Due to C1-Inhibitor Deficiency. Clin. Exp. Immunol. 2012, 167, 472-478. [CrossRef]

78. Baker, S.K.; Chen, Z.-L.; Norris, E.H.; Revenko, A.S.; MacLeod, A.R.; Strickland, S. Blood-Derived Plasminogen Drives Brain Inflammation and Plaque Deposition in a Mouse Model of Alzheimer's Disease. Proc. Natl. Acad. Sci. USA 2018, 115, 9687-9696. [CrossRef]

79. Chen, Z.-L.; Revenko, A.S.; Singh, P.; MacLeod, A.R.; Norris, E.H.; Strickland, S. Depletion of Coagulation Factor XII Ameliorates Brain Pathology and Cognitive Impairment in Alzheimer Disease Mice. Blood 2017, 129, 2547-2556. [CrossRef]

80. Draxler, D.F.; Lee, F.; Ho, H.; Keragala, C.B.; Medcalf, R.L.; Niego, B. t-PA Suppresses the Immune Response and Aggravates Neurological Deficit in a Murine Model of Ischemic Stroke. Front Immunol. 2019, 10, 591. [CrossRef]

81. Graham, C.H.; Fitzpatrick, T.E.; McCrae, K.R. Hypoxia Stimulates Urokinase Receptor Expression through a Heme ProteinDependent Pathway. Blood 1998, 91, 3300-3307. [CrossRef] [PubMed]

82. E Kroon, M.; Koolwijk, P.; Van Der Vecht, B.; Van Hinsbergh, V.W. Urokinase Receptor Expression on Human Microvascular Endothelial Cells is Increased by Hypoxia: Implications for Capillary-Like Tube Formation in a Fibrin Matrix. Blood 2000, 96, 2775-2783. [CrossRef]

83. Krock, B.L.; Skuli, N.; Simon, M.C. Hypoxia-Induced Angiogenesis: Good and Evil. Genes Cancer 2011, 2, 1117-1133. [CrossRef] [PubMed]

84. del Zoppo, G.J.; Higashida, R.T.; Furlan, A.J.; Pessin, M.S.; Rowley, H.A.; Gent, M. PROACT: A Phase II Randomized Trial of Recombinant Pro-Urokinase by Direct Arterial Delivery in Acute Middle Cerebral Artery Stroke. PROACT Investigators. Prolyse in Acute Cerebral Thromboembolism. Stroke 1998, 29, 4-11. [CrossRef]

85. Wardlaw, J.M. Overview of Cochrane Thrombolysis Meta-Analysis. Neurology 2001, 57, 69-76. [CrossRef]

86. Zhang, X.; Polavarapu, R.; She, H.; Mao, Z.; Yepes, M. Tissue-Type Plasminogen Activator and the Low-Density Lipoprotein Receptor-Related Protein Mediate Cerebral Ischemia-Induced Nuclear Factor-kappaB Pathway Activation. Am. J. Pathol. 2007, 171, 1281-1290. [CrossRef]

87. Yepes, M.; Sandkvist, M.; Moore, E.G.; Bugge, T.H.; Strickland, D.K.; Lawrence, D.A. Tissue-Type Plasminogen Activator Induces Opening of the Blood-Brain Barrier via the LDL Receptor-Related Protein. J. Clin. Investig. 2003, 112, 1533-1540. [CrossRef]

88. Kidwell, C.S.; Latour, L.; Saver, J.L.; Alger, J.R.; Starkman, S.; Duckwiler, G.; Jahan, R.; Viñuela, F.; Kang, D.-W.; Warach, S. Thrombolytic Toxicity: Blood Brain Barrier Disruption in Human Ischemic Stroke. Cerebrovasc. Dis. 2008, 25, 338-343. [CrossRef]

89. Zhang, L.; Li, Y.; Zhang, C.; Chopp, M.; Gosiewska, A.; Hong, K. Delayed Administration of Human Umbilical Tissue-Derived Cells Improved Neurological Functional Recovery in a Rodent Model of Focal Ischemia. Stroke 2011, 42, 1437-1444. [CrossRef]

90. Bretscher, A.; A Edwards, K.; Fehon, R.G. ERM Proteins and Merlin: Integrators at the Cell Cortex. Nat. Rev. Mol. Cell Biol. 2002, 3, 586-599. [CrossRef]

91. Tsukita, S.; Yonemura, S. Cortical Actin Organization: Lessons from ERM (Ezrin/Radixin/Moesin) Proteins. J. Biol. Chem. 1999, 274, 34507-34510. [CrossRef]

92. Fehon, R.G.; McClatchey, A.I.; Bretscher, A. Organizing the Cell Cortex: The Role of ERM Proteins. Nat. Rev. Mol. Cell Biol. 2010, 11, 276-287. [CrossRef]

93. Reichenbach, A.; Derouiche, A.; Kirchhoff, F. Morphology and Dynamics of Perisynaptic Glia. Brain Res. Rev. 2010, 63, 11-25. [CrossRef]

94. Lavialle, M.; Aumann, G.; Anlauf, E.; Pröls, F.; Arpin, M.; Derouiche, A. Structural Plasticity of Perisynaptic Astrocyte Processes Involves Ezrin and Metabotropic Glutamate Receptors. Proc. Natl. Acad. Sci. USA 2011, 108, 12915-12919. [CrossRef]

95. Taylor, R.A.; Sansing, L.H. Microglial Responses after Ischemic Stroke and Intracerebral Hemorrhage. Clin. Dev. Immunol. 2013, 2013, 1-10. [CrossRef]

96. Gravanis, I.; Tsirka, S.E. Tissue Plasminogen Activator and Glial Function. Glia 2004, 49, 177-183. [CrossRef]

97. Zhang, C.; An, J.; Strickland, D.K.; Yepes, M. The Low-Density Lipoprotein Receptor-Related Protein 1 Mediates Tissue-Type Plasminogen Activator-Induced Microglial Activation in the Ischemic Brain. Am. J. Pathol. 2009, 174, 586-594. [CrossRef]

98. Su, E.J.; Fredriksson, L.; Geyer, M.; Folestad, E.; Cale, J.; Andrae, J.; Gao, Y.; Pietras, K.; Mann, K.; Yepes, M.; et al. Activation of PDGF-CC by Tissue Plasminogen Activator Impairs Blood-Brain Barrier Integrity during Ischemic Stroke. Nat. Med. 2008, 14, 731-737. [CrossRef] 
99. Kuo, P.C.; Weng, W.T.; Scofield, B.A.; Furnas, D.; Paraiso, H.C.; Intriago, A.J.; Bosi, K.D.; Yu, I.C.; Yen, J.H. Interferon-Beta Alleviates Delayed tPA-Induced Adverse Effects via Modulation of MMP3/9 Production in Ischemic Stroke. Blood Adv. 2020, 4, 4366-4381. [CrossRef]

100. Washington, R.A.; Becher, B.; Balabanov, R.; Antel, J.; Dore-Duffy, P. Expression of the Activation Marker Urokinase PlasminogenActivator Receptor in Cultured Human Central Nervous System Microglia. J. Neurosci. Res. 1996, 45, 392-399. [CrossRef]

101. Cunningham, O.; Campion, S.; Perry, V.H.; Murray, C.; Sidenius, N.; Docagne, F.; Cunningham, C. Microglia and the urokinase plasminogen activator receptor/uPA system in innate brain inflammation. Glia 2009, 57, 1802-1814. [CrossRef] [PubMed]

102. Shin, S.M.; Cho, K.S.; Choi, M.S.; Lee, S.H.; Han, S.-H.; Kang, Y.-S.; Kim, H.J.; Cheong, J.H.; Shin, C.Y.; Ko, K.H. Urokinase-Type Plasminogen Activator Induces BV-2 Microglial Cell Migration Through Activation of Matrix Metalloproteinase-9. Neurochem. Res. 2010, 35, 976-985. [CrossRef] [PubMed]

103. Wang, Y.F.; Tsirka, S.E.; Strickland, S.; Stieg, P.E.; Soriano, S.G.; Lipton, S.A. Tissue plasminogen activator (tPA) increase neuronal damage after focal cerebral ischemia in wild-type and tPA-deficient mice. Nat. Med. 1998, 4, 228-231. [CrossRef] [PubMed]

104. Echeverry, R.; Wu, J.; Haile, W.B.; Guzman, J.; Yepes, M. Tissue-type plasminogen activator is a neuroprotectant in the mouse hippocampus. J. Clin. Investig. 2010, 120, 2194-2205. [CrossRef] [PubMed]

105. Nagai, N.; De Mol, M.; Lijnen, H.R.; Carmeliet, P.; Collen, D. Role of Plasminogen System Components in Focal Cerebral Ischemic Infarction: A Gene Targeting and Gene Transfer Study in Mice. Circulation 1999, 99, 2440-2444. [CrossRef] [PubMed]

106. Tabrizi, P.; Wang, L.; Seeds, N.; McComb, J.G.; Yamada, S.; Griffin, J.H.; Carmeliet, P.; Weiss, M.H.; Zlokovic, B.V. Tissue Plasminogen Activator (tPA) Deficiency Exacerbates Cerebrovascular Fibrin Deposition and Brain Injury in a Murine Stroke Model: Studies in tPA-Deficient Mice and Wild-Type Mice on a Matched Genetic Background. Arterioscler. Thromb. Vasc. Biol. 1999, 19, 2801-2806. [CrossRef]

107. Wu, F.; Wu, J.; Nicholson, A.D.; Echeverry, R.; Haile, W.B.; Catano, M.; An, J.; Lee, A.K.; Duong, D.; Dammer, E.B.; et al. Tissue-Type Plasminogen Activator Regulates the Neuronal Uptake of Glucose in the Ischemic Brain. J. Neurosci. 2012, 32, 9848-9858. [CrossRef]

108. Klein, G.M.; Li, H.; Sun, P.; Buchan, A.M. Tissue Plasminogen Activator does not Increase Neuronal Damage in Rat Models of Global and Focal Ischemia. Neurology 1999, 52, 1381-1384. [CrossRef]

109. Hacke, W.; ATLANTIS Trials Investigators; ECASS Trials Investigators; NINDS rt-PA Study Group Investigators. Association of Outcome with Early Stroke Treatment: Pooled Analysis of ATLANTIS, ECASS, and NINDS rt-PA Stroke Trials. Lancet 2004, $363,768-774$.

110. Adams, H.P., Jr.; Del Zoppo, G.; Alberts, M.J.; Bhatt, D.L.; Brass, L.; Furlan, A.; Grubb, R.L.; Higashida, R.T.; Jauch, E.C.; Kidwell, C.; et al. Guidelines for the Early Management of Adults with Ischemic Stroke: A Guideline from the American Heart Association/American Stroke Association Stroke Council, Clinical Cardiology Council, Cardiovascular Radiology and Intervention Council, and the Atherosclerotic Peripheral Vascular Disease and Quality of Care Outcomes in Research Interdisciplinary Working Groups: The American Academy of Neurology affirms the value of this guideline as an educational tool for neurologists. Circulation 2007, 115, 478-534.

111. Haile, W.B.; Wu, J.; Echeverry, R.; Wu, F.; An, J.; Yepes, M. Tissue-Type Plasminogen Activator has a Neuroprotective Effect in the Ischemic Brain Mediated by Neuronal TNF- $\alpha$. J. Cereb. Blood Flow Metab. 2012, 32, 57-69. [CrossRef]

112. Tsirka, S.E.; Gualandris, A.; Amaral, D.G.; Strickland, S. Excitotoxin-induced neuronal degeneration and seizure are mediated by tissue plasminogen activator. Nat. Cell Biol. 1995, 377, 340-344. [CrossRef]

113. Chen, Z.-L.; Strickland, S. Neuronal Death in the Hippocampus Is Promoted by Plasmin-Catalyzed Degradation of Laminin. Cell 1997, 91, 917-925. [CrossRef]

114. Reddrop, C.; Moldrich, R.X.; Beart, P.M.; Farso, M.; Liberatore, G.T.; Howells, D.W.; Petersen, K.-U.; Schleuning, W.-D.; Medcalf, R.L. Vampire Bat Salivary Plasminogen Activator (Desmoteplase) Inhibits Tissue-Type Plasminogen Activator-Induced Potentiation of Excitotoxic Injury. Stroke 2005, 36, 1241-1246. [CrossRef]

115. Wu, F.; Echeverry, R.; Wu, J.; An, J.; Haile, W.B.; Cooper, D.S.; Catano, M.; Yepes, M. Tissue-Type Plasminogen Activator Protects Neurons from Excitotoxin-Induced Cell Death via Activation of the ERK1/2-CREB-ATF3 Signaling Pathway. Mol. Cell Neurosci. 2013, 52, 9-19. [CrossRef]

116. Salles, F.J.; Strickland, S. Localization and Regulation of the Tissue Plasminogen Activator-Plasmin System in the Hippocampus. J. Neurosci. 2002, 22, 2125-2134. [CrossRef]

117. Kim, Y.H. Nonproteolytic Neuroprotection by Human Recombinant Tissue Plasminogen Activator. Science 1999, 284, 647-650. [CrossRef]

118. Parcq, J.; Bertrand, T.; Montagne, A.; Baron, A.F.; Macrez, R.; Billard, J.M.; Briens, A.; Hommet, Y.; Wu, J.; Yepes, M.; et al. Unveiling an Exceptional Zymogen: The Single-Chain Form of tPA is a Selective Activator of NMDA Receptor-Dependent Signaling and Neurotoxicity. Cell Death Differ. 2012, 19, 1983-1991. [CrossRef]

119. Anfray, A.; Brodin, C.; Drieu, A.; Potzeha, F.; Dalarun, B.; Agin, V.; Vivien, D.; Orset, C. Single- and Two- Chain Tissue Type Plasminogen Activator Treatments Differentially Influence Cerebral Recovery after Stroke. Exp. Neurol. 2021, 338, 113606. [CrossRef]

120. Nagai, N.; Okada, K.; Kawao, N.; Ishida, C.; Ueshima, S.; Collen, D.; Matsuo, O. Urokinase-Type Plasminogen Activator receptor (uPAR) Augments Brain Damage in a Murine Model of Ischemic Stroke. Neurosci. Lett. 2008, 432, 46-49. [CrossRef]

121. Morales, D.; McIntosh, T.; Conte, V.; Fujimoto, S.; Graham, D.; Grady, M.S.; Stein, S.C. Impaired Fibrinolysis and Traumatic Brain Injury in Mice. J. Neurotrauma 2006, 23, 976-984. [CrossRef] [PubMed] 
122. Yu, X.; Ji, C.; Shao, A. Neurovascular Unit Dysfunction and Neurodegenerative Disorders. Front. Neurosci. 2020, $14,334$. [CrossRef] [PubMed]

123. Zlokovic, B.V. The Blood-Brain Barrier in Health and Chronic Neurodegenerative Disorders. Neuron 2008, 57, $178-201$. [CrossRef] [PubMed]

124. Sloane, P.D.; Zimmerman, S.; Suchindran, C.; Reed, P.; Wang, L.; Boustani, M.; Sudha, S. The Public Health Impact of Alzheimer's Disease, 2000-2050: Potential Implication of Treatment Advances. Annu. Rev. Public Health 2002, $23,213-231$. [CrossRef] [PubMed]

125. Kelleher, R.J.; Soiza, R.L. Evidence of Endothelial Dysfunction in the Development of Alzheimer's Disease: Is Alzheimer's a Vascular Disorder? Am. J. Cardiovasc. Dis. 2013, 3, 197-226. [PubMed]

126. Kisler, K.; Nelson, A.R.; Montagne, A.; Zlokovic, B.V. Cerebral Blood Flow Regulation and Neurovascular Dysfunction in Alzheimer Disease. Nat. Rev. Neurosci. 2017, 18, 419-434. [CrossRef] [PubMed]

127. Sweeney, M.D.; Kisler, K.; Montagne, A.; Toga, A.W.; Zlokovic, B.V. The role of brain vasculature in neurodegenerative disorders. Nat. Neurosci. 2018, 21, 1318-1331. [CrossRef]

128. Park, L.; Zhou, J.; Koizumi, K.; Wang, G.; Anfray, A.; Ahn, S.J.; Seo, J.; Zhou, P.; Zhao, L.; Paul, S.; et al. tPA Deficiency Underlies Neurovascular Coupling Dysfunction by Amyloid-beta. J. Neurosci. 2020, 40, 8160-8173. [CrossRef]

129. Davis, J.; Wagner, M.R.; Zhang, W.; Xu, F.; Van Nostrand, W.E. Amyloid Beta-Protein Stimulates the Expression of Urokinase-Type Plasminogen Activator (uPA) and Its Receptor (uPAR) in Human Cerebrovascular Smooth Muscle Cells. J. Biol. Chem. 2003, 278, 19054-19061. [CrossRef]

130. Storck, S.E.; Meister, S.; Nahrath, J.; Meißner, J.N.; Schubert, N.; Di Spiezio, A.; Baches, S.; Vandenbroucke, R.E.; Bouter, Y.; Prikulis, I.; et al. Endothelial LRP1 Transports Amyloid-Beta(1-42) Across the Blood-Brain Barrier. J. Clin. Investig. 2016, 126, 123-136. [CrossRef]

131. Lillis, A.P.; Mikhailenko, I.; Strickland, D.K. Beyond Endocytosis: LRP Function in Cell Migration, Proliferation and Vascular Permeability. J. Thromb. Haemost. 2005, 3, 1884-1893. [CrossRef]

132. Rodríguez-Arellano, J.; Parpura, V.; Zorec, R.; Verkhratsky, A. Astrocytes in Physiological Aging and Alzheimer's Disease. Neurosci. 2016, 323, 170-182. [CrossRef]

133. A Bates, K.; Fonte, J.; A Robertson, T.; Martins, R.N.; Harvey, A.R. Chronic Gliosis Triggers Alzheimer's Disease-Like Processing of Amyloid Precursor Protein. Neurosci. 2002, 113, 785-796. [CrossRef]

134. Habib, N.; McCabe, C.; Medina, S.; Varshavsky, M.; Kitsberg, D.; Dvir-Szternfeld, R.; Green, G.; Dionne, D.; Nguyen, L.; Marshall, J.L.; et al. Disease-Associated Astrocytes in Alzheimer's Disease and Aging. Nat. Neurosci. 2020, 23, 701-706. [CrossRef]

135. Ballabh, P.; Braun, A.; Nedergaard, M. The Blood-Brain Barrier: An Overview: Structure, Regulation, and Clinical Implications. Neurobiol. Dis. 2004, 16, 1-13. [CrossRef]

136. Montagne, A.; Barnes, S.R.; Sweeney, M.D.; Halliday, M.R.; Sagare, A.P.; Zhao, Z.; Toga, A.W.; Jacobs, R.E.; Liu, C.Y.; Amezcua, L.; et al. Blood-Brain Barrier Breakdown in the Aging Human Hippocampus. Neuron 2015, 85, 296-302. [CrossRef]

137. Kuchibhotla, K.V.; Lattarulo, C.R.; Hyman, B.T.; Bacskai, B.J. Synchronous Hyperactivity and Intercellular Calcium Waves in Astrocytes in Alzheimer Mice. Science 2009, 323, 1211-1215. [CrossRef]

138. Hemonnot, A.-L.; Hua, J.; Ulmann, L.; Hirbec, H. Microglia in Alzheimer Disease: Well-Known Targets and New Opportunities. Front. Aging Neurosci. 2019, 11, 233. [CrossRef] [PubMed]

139. Griffin, W.S.; Stanley, L.C.; Ling, C.; White, L.; MacLeod, V.; Perrot, L.J.; White, C.L.; Araoz, C. Brain interleukin 1 and S-100 immunoreactivity are elevated in Down syndrome and Alzheimer disease. Proc. Natl. Acad. Sci. USA 1989, 86, 7611-7615. [CrossRef] [PubMed]

140. Hansen, D.V.; Hanson, J.E.; Sheng, M. Microglia in Alzheimer's Disease. J. Cell Biol. 2018, 217, 459-472. [CrossRef]

141. Mehra, A.; Ali, C.; Parcq, J.; Vivien, D.; Docagne, F. The Plasminogen Activation System in Neuroinflammation. Biochim. et Biophys. Acta (BBA) Mol. Basis Dis. 2016, 1862, 395-402. [CrossRef]

142. ElAli, A.; Bordeleau, M.; Thériault, P.; Filali, M.; Lampron, A.; Rivest, S. Tissue-Plasminogen Activator Attenuates Alzheimer's Disease-Related Pathology Development in APPswe/PS1 Mice. Neuropsychopharmacology 2016, 41, 1297-1307. [CrossRef] [PubMed]

143. Walker, D.G.; Lue, L.F.; Beach, T.G. Increased Expression of the Urokinase Plasminogen-Activator Receptor in Amyloid Beta Peptide-Treated Human Brain Microglia and in AD Brains. Brain Res. 2002, 926, 69-79. [CrossRef]

144. Hopperton, K.E.; Mohammad, D.; O Trépanier, M.; Giuliano, V.; Bazinet, R.P. Markers of Microglia in Post-Mortem Brain Samples from Patients with Alzheimer's Disease: A Systematic Review. Mol. Psychiatry 2018, 23, 177-198. [CrossRef]

145. Hawkins, B.T.; Davis, T.P. The Blood-Brain Barrier/Neurovascular Unit in Health and Disease. Pharmacol. Rev. 2005, 57, 173-185. [CrossRef]

146. Muller, U.C.; Deller, T.; Korte, M. Not Just Amyloid: Physiological Functions of the Amyloid Precursor Protein Family. Nat. Rev. Neurosci. 2017, 18, 281-298. [CrossRef]

147. Selkoe, D.J. Toward a Comprehensive Theory for Alzheimer's Disease. Hypothesis: Alzheimer's Disease is Caused by the Cerebral Accumulation and Cytotoxicity of Amyloid Beta-Protein. Ann. NY Acad. Sci. 2000, 924, 17-25. [CrossRef]

148. Selkoe, D.J.; Yamazaki, T.; Citron, M.; Podlisny, M.B.; Koo, E.H.; Teplow, D.B.; Haass, C. The Role of APP Processing and Trafficking Pathways in the Formation of Amyloid Beta-Protein. Ann. NY Acad. Sci. 1996, 777, 57-64. [CrossRef] 
149. Kamenetz, F.; Tomita, T.; Hsieh, H.; Seabrook, G.; Borchelt, D.; Iwatsubo, T.; Sisodia, S.; Malinow, R. APP Processing and Synaptic Function. Neuron 2003, 37, 925-937. [CrossRef]

150. Blennow, K.; de Leon, M.J.; Zetterberg, H. Alzheimer's Disease. Lancet 2006, 368, 387-403. [CrossRef]

151. Collaborators, G.B.D.D. Global, Regional, and National Burden of Alzheimer's Disease and Other Dementias, 1990-2016: A Systematic Analysis for the Global Burden of Disease Study 2016. Lancet Neurol. 2019, 18, 88-106.

152. Almeida, C.G.; Tampellini, D.; Takahashi, R.H.; Greengard, P.; Lin, M.T.; Snyder, E.M.; Gouras, G.K. Beta-Amyloid Accumulation in APP Mutant Neurons Reduces PSD-95 and GluR1 in Synapses. Neurobiol. Dis. 2005, 20, 187-198. [CrossRef] [PubMed]

153. Aizenstein, H.J.; Nebes, R.D.; Saxton, J.A.; Price, J.C.; Mathis, C.A.; Tsopelas, N.D.; Ziolko, S.K.; James, J.A.; Snitz, B.E.; Houck, P.R.; et al. Frequent Amyloid Deposition Without Significant Cognitive Impairment Among the Elderly. Arch. Neurol. 2008, 65, 1509-1517. [CrossRef] [PubMed]

154. Lowe, S.L.; Willis, B.A.; Hawdon, A.; Natanegara, F.; Chua, L.; Foster, J.; Shcherbinin, S.; Ardayfio, P.; Sims, J.R. Donanemab (LY3002813) Dose-Escalation Study in Alzheimer's Disease. Alzheimers Dement (NY) 2021, 7, e12112.

155. Ledesma, M.D.; Da Silva, J.S.; Crassaerts, K.; Delacourte, A.; De Strooper, B.; Dotti, C.G. Brain Plasmin Enhances APP AlphaCleavage and Abeta Degradation and is Reduced in Alzheimer's Disease Brains. EMBO Rep. 2000, 1, 530-535. [CrossRef]

156. Tucker, H.M.; Kihiko, M.; Caldwell, J.N.; Wright, S.; Kawarabayashi, T.; Price, D.; Walker, D.; Scheff, S.; McGillis, J.P.; Rydel, R.E.; et al. The Plasmin System is Induced by and Degrades Amyloid-Beta Aggregates. J. Neurosci. 2000, 20, 3937-3946. [CrossRef]

157. Tucker, H.M.; Kihiko-Ehmann, M.; Wright, S.; Rydel, R.E.; Estus, S. Tissue Plasminogen Activator Requires Plasminogen to Modulate Amyloid-Beta Neurotoxicity and Deposition. J. Neurochem. 2000, 75, 2172-2177. [CrossRef]

158. Fabbro, S.; Seeds, N.W. Plasminogen activator activity is inhibited while neuroserpin is up-regulated in the Alzheimer disease brain. J. Neurochem. 2009, 109, 303-315. [CrossRef]

159. Barker, R.; Love, S.; Kehoe, P.G. Plasminogen and Plasmin in Alzheimer's Disease. Brain Res. 2010, 1355, 7-15. [CrossRef]

160. Dotti, C.G.; Galvan, C.; Ledesma, M.D. Plasmin Deficiency in Alzheimer's Disease Brains: Causal or Casual? Neurodegener. Dis. 2004, 1, 205-212. [CrossRef]

161. Kingston, I.B.; Castro, M.J.; Anderson, S. In Vitro Stimulation of Tissue-Type Plasminogen Activator by Alzheimer Amyloid Beta-Peptide Analogues. Nat. Med. 1995, 1, 138-142. [CrossRef] [PubMed]

162. Melchor, J.P.; Pawlak, R.; Strickland, S. The Tissue Plasminogen Activator-Plasminogen Proteolytic Cascade Accelerates AmyloidBeta (Abeta) Degradation and Inhibits Abeta-Induced Neurodegeneration. J. Neurosci. 2003, 23, 8867-8871. [CrossRef] [PubMed]

163. Sutton, R.; Keohane, M.E.; Vandenberg, S.R.; Gonias, S.L. Plasminogen activator inhibitor-1 in the cerebrospinal fluid as an index of neurological disease. Blood Coagul. Fibrinolysis 1994, 5, 167-172. [CrossRef] [PubMed]

164. Liu, R.M.; Van Groen, T.; Katre, A.; Cao, D.; Kadisha, I.; Ballinger, C.; Wang, L.; Carroll, S.L.; Li, L. Knockout of Plasminogen Activator Inhibitor 1 Gene Reduces Amyloid Beta Peptide Burden in a Mouse Model of Alzheimer's Disease. Neurobiol. Aging 2011, 32, 1079-1089. [CrossRef]

165. Medina, M.G.; Ledesma, M.D.; Domínguez, J.E.; Medina, M.; Zafra, D.; Alameda, F.; Dotti, C.G.; Navarro, P. Tissue Plasminogen Activator Mediates Amyloid-Induced Neurotoxicity via Erk1/2 Activation. EMBO J. 2005, 24, 1706-1716. [CrossRef]

166. Tucker, H.M.; Kihiko-Ehmann, M.; Estus, S. Urokinase-Type Plasminogen Activator Inhibits Amyloid-Beta Neurotoxicity and Fibrillogenesis via Plasminogen. J. Neurosci. Res. 2002, 70, 249-255. [CrossRef]

167. Price, J.L.; Morris, J.C. Tangles and Plaques in Nondemented Aging and "Preclinical" Alzheimer's Disease. Ann. Neurol. 1999, 45, 358-368. [CrossRef]

168. Terry, R.D.; Masliah, E.; Salmon, D.P.; Butters, N.; DeTeresa, R.; Hill, R.; Hansen, L.A.; Katzman, R. Physical Basis of Cognitive Alterations in Alzheimer's Disease: Synapse Loss is the Major Correlate of Cognitive Impairment. Ann. Neurol. 1991, 30, 572-580. [CrossRef]

169. Selkoe, D.J. Alzheimer's Disease is A Synaptic Failure. Science 2002, 298, 789-791. [CrossRef]

170. Palop, J.J.; Mucke, L. Amyloid-Beta-Induced Neuronal Dysfunction in Alzheimer's Disease: From Synapses toward Neural Networks. Nat Neurosci. 2010, 13, 812-818. [CrossRef]

171. Hsieh, H.; Boehm, J.; Sato, C.; Iwatsubo, T.; Tomita, T.; Sisodia, S.; Malinow, R. AMPAR Removal Underlies Abeta-Induced Synaptic Depression and Dendritic Spine Loss. Neuron 2006, 52, 831-843. [CrossRef]

172. Li, S.; Hong, S.; Shepardson, N.E.; Walsh, D.M.; Shankar, G.M.; Selkoe, D. Soluble Oligomers of Amyloid Beta Protein Facilitate Hippocampal Long-Term Depression by Disrupting Neuronal Glutamate Uptake. Neuron 2009, 62, 788-801. [CrossRef]

173. Cleary, J.P.; Walsh, D.M.; Hofmeister, J.J.; Shankar, G.M.; Kuskowski, M.A.; Selkoe, D.J.; Ashe, K.H. Natural Oligomers of the Amyloid-Beta Protein Specifically Disrupt Cognitive Function. Nat. Neurosci. 2005, 8, 79-84. [CrossRef]

174. Stratton, J.R.; Chandler, W.L.; Schwartz, R.S.; Cerqueira, M.D.; Levy, W.C.; E Kahn, S.; Larson, V.G.; Cain, K.C.; Beard, J.C.; Abrass, I.B. Effects of physical conditioning on fibrinolytic variables and fibrinogen in young and old healthy adults. Circulation 1991, 83, 1692-1697. [CrossRef]

175. Yaffe, K.; Barnes, D.; Nevitt, M.; Lui, L.Y.; Covinsky, K. A Prospective Study of Physical Activity and Cognitive Decline in Elderly Women: Women Who Walk. Arch. Intern. Med. 2001, 161, 1703-1708. [CrossRef]

176. Smith, P.J.; Blumenthal, J.A.; Hoffman, B.M.; Cooper, H.; Strauman, T.A.; Welsh-Bohmer, K.; Browndyke, J.N.; Sherwood, A. Aerobic Exercise and Neurocognitive Performance: A Meta-Analytic Review of Randomized Controlled Trials. Psychosom. Med. 2010, 72, 239-252. [CrossRef] 
177. Poewe, W.; Seppi, K.; Tanner, C.M.; Halliday, G.M.; Brundin, P.; Volkmann, J.; Schrag, A.E.; Lang, A.E. Parkinson Disease. Nat. Rev. Dis. Primers. 2017, 3, 17013. [CrossRef]

178. Kim, K.S.; Choi, Y.R.; Park, J.Y.; Lee, J.H.; Kim, D.K.; Lee, S.J.; Paik, S.R.; Jou, I.; Park, S.M. Proteolytic Cleavage of Extracellular Alpha-Synuclein by Plasmin: Implications for Parkinson Disease. J. Biol. Chem. 2012, 287, 24862-24872. [CrossRef]

179. Reuland, C.J.; Church, F.C. Synergy between plasminogen activator inhibitor-1, $\alpha$-synuclein, and neuroinflammation in Parkinson's disease. Med. Hypotheses 2020, 138, 109602. [CrossRef]

180. Pan, H.; Zhao, Y.; Zhai, Z.; Zheng, J.; Zhou, Y.; Zhai, Q.; Cao, X.; Tian, J.; Zhao, L. Role of Plasminogen Activator Inhibitor-1 in the Diagnosis and Prognosis of Patients with Parkinson's Disease. Exp. Ther. Med. 2018, 15, 5517-5522. [CrossRef]

181. Demestre, M.; Howard, R.S.; Orrell, R.W.; Pullen, A.H. Serine proteases purified from sera of patients with amyotrophic lateral sclerosis (ALS) induce contrasting cytopathology in murine motoneurones to IgG. Neuropathol. Appl. Neurobiol. 2006, 32, 141-156. [CrossRef] [PubMed]

182. Glas, M.; Popp, B.; Angele, B.; Koedel, U.; Chahli, C.; Schmalix, W.; Anneser, J.; Pfister, H.; Lorenzl, S. A role for the urokinase-type plasminogen activator system in amyotrophic lateral sclerosis. Exp. Neurol. 2007, 207, 350-356. [CrossRef] [PubMed] 